\title{
NORMATIVA SUSTANTIVO-PENAL DURANTE LOS GOBIERNOS DE AYLWIN, FREI Y LAGOS. CHILE: ¿UN CASO DE EXPANSIÓN O INTENSIFICACIÓN DEL DERECHO PENAL?
}

\author{
Joaquin Ignacio Nilo Valdebenito*
}

\begin{abstract}
Resumen
El autor sistematiza las leyes de carácter penal sustantivo publicadas durante el período comprendido entre el 11 de marzo de 1990 y el 11 de marzo de 2006. Se busca con ello comprobar si es que en Chile es posible afirmar la existencia de un fenómeno de expansión del Derecho Penal, verificando si las características de este proceso, descrito por Jesús-María Silva Sánchez, son aplicables a la realidad nacional. Se concluye que, si bien nuestro Derecho Penal participa de ciertas características que son propias de la "expansión", lo que hace que se reconozca la presencia de ciertos fenómenos catalogados como causas de ella, ello no significa que pueda calificarse pura y simplemente su existencia, sino que se está más bien frente a una "intensificación" de nuestro Derecho Penal sustantivo.
\end{abstract}

Palabras clave: Legislación penal sustantiva, reduccionismo penal, criminalización, expansión, intensificación.

\begin{abstract}
The author systematized the substantive criminal laws, issued during the period from March 11, 1990 and 11 March, 2006. Wanted to check it, if that Chile is possible or not, assert the existence of a phenomenon of expansion of criminal law, verifying if the characteristics of this process, described by Jesús-María Silva Sánchez, apply or not to national reality. We conclude that, although our criminal law, shares certain characteristics that are peculiar to the "expansion", which makes the recognition of the presence of certain phenomena listed as causes of it, this does not mean you can simply described their existence, but rather, it is estimated that faces an "intensification" of our substantive criminal law.
\end{abstract}

Key words: Criminal legislation, criminal-law reductionism, criminalization, expansion, intensification.

Introducción; 1. Fenomenología de leyes; 1.1 Reduccionismo penal y criminalización; 1.1.1 Contexto bistórico en que se dan los fenómenos de morigeración penal y criminalización, en los gobiernos de Aylwin, Frei y Lagos; 1.1.2 Sobre qué materia versan las leyes sustantivo-penales: a) En la agrupación de leyes sustantivo-penales adscritas a un "reduccionismo penal"; b) En la agrupación criminalizadora. Materia sobre la cual versan dichas leyes sustantivo-penales y bien jurídico tutelado; 2. Causas de la expansión del Derecho Penal segín Jesús Silva Sánchez; 2.1 Contraste entre las causas de expansión del Derecho Penal y la realidad nacional; Conclusiones.

\footnotetext{
* Magíster en Derecho Penal. Juez Oral en lo Penal de Rancagua, email: jnilo@utalca.cl
} 


\section{Introducción}

En la presente investigación se analizaron los cuerpos legales de carácter penal sustantivo que se publicaron entre el día 11 de marzo de 1990 y el 11 de marzo de 2006, fracción temporal correspondiente a los períodos presidenciales de los gobiernos de Patricio Aylwin, Eduardo Frei y Ricardo Lagos. Tal estudio abarca todas aquellas leyes con "injerencia penal sustantivo", resultado final que requirió un análisis previo de todos los cuerpos normativos publicados en el período que dijeran relación, sea en su tópica general, en cuanto a la materia regulada, con Derecho Penal, como asimismo de toda aquella legislación generada como ley durante el período, que incluyeran en alguna parte de su articulado, voces como "penal", "responsabilidad penal", "delito", "presidio", "prisión", "sancionado" o "multa". Tal operación se llevó a cabo entre los meses de octubre de 2008 y mayo de 2009, y se utilizaron para la obtención de la información requerida las bases de datos de la Biblioteca del Congreso Nacional y de las páginas web www.legalpublishing.cl y www.senado.cl.

La operación anterior llevó a tener una preselección de leyes (alrededor de 130), que se estudiaron una por una, artículo por artículo, y que, conforme a los objetivos trazados para este estudio, dejó fuera de su alcance todas las normas de tinte procesal penal y, además, aquellas que, no obstante contener la pena de multa en alguna de sus disposiciones, por su naturaleza se calificaron como de índole administrativa y no penal. Así, tal discriminación se definió, de una parte, a partir de aquellas que poseían una distinta denominación a la establecida en el artículo 21 del Código Penal [verbigracia, "multa a beneficio fiscal" quedó fuera del estudio], y de otra parte, en las que poseían como tribunal competente para decretarlas y conocer del procedimiento respectivo a un ente jurisdiccional diferente de aquel que conoce materias propias de lo penal, en cuanto juzgamiento de crímenes, simples delitos y faltas, descontando de estas últimas lo propio de la jurisdicción de los Juzgados de Policía Local y de Tribunales Especiales, que se avoquen a procedimientos de carácter infraccional [por ejemplo, la ley $\mathrm{N}^{\circ} 19.496$, sobre protección de los derechos del consumidor]. Sin embargo, a estas últimas, sí se les consideró en infra 4.1.1. a), por la naturaleza del tema que allí se trató y, en particular, cuando se analizó la ley $\mathrm{N}^{\circ} 19.911$, que crea el Tribunal de Defensa de la Libre Competencia.

De tal forma, como parte central de este estudio, se incluyeron a modo de hipótesis y se les dio el carácter de penal sustantivo a las siguientes leyes: a) toda ley que incorporara dentro de su articulado la tipificación de una conducta, sea con la inclusión de nuevos comportamientos asociados a una sanción, como de aquellas circunstancias que implicaran una mutación de su descripción vigente, como también cuando se derogaran tipos penales ya existentes; b) toda regulación que dispusiera la existencia, modificación o supresión de circunstancias modificatorias de responsabilidad, como del establecimiento de eximentes de responsabilidad criminal, indultos u otra forma de exención especial; finalmente, 
c) todas aquellas disposiciones destinadas a extender o reducir el ámbito de lo punible, sea por la simple mutación de una sanción, para hacerla más o menos gravosa, o castigando grados de desarrollo imperfecto de los delitos como figuras completas, grados de participación de menor entidad como autoría o actos preparatorios como ilicitudes independientes.

Así, si el límite de fondo en cuanto a lo que se entendió por normativa con injerencia penal sustantiva estuvo en la agrupación antes explicitada, el acotamiento formal de la sistematización de leyes incluyó normas de carácter general contenidas en el Código Penal o en leyes penales especiales, pero también abarcó otros cuerpos legales específicos de otras áreas del derecho, que incorporarán en su preceptiva algunas de las hipótesis calificadas como de incidencia o injerencia penal sustantiva antes mencionadas.

De esta forma, se estudió el conjunto de leyes publicadas en el período, y de acuerdo con la metodología por la que se optó, se filtraron y seleccionaron finalmente un total de 102 leyes de injerencia penal sustantiva, desde la $\mathrm{N}^{\circ} 18.978$, sobre concesión de indulto general a las personas que indica, publicada el 14 de mayo de 1990, correspondiente al gobierno de Patricio Aylwin, hasta la $\mathrm{N}^{\mathrm{o}} 20.090$, que sanciona con mayor vigor el abigeato y facilita su investigación, norma publicada el día 11 de enero de 2006, dictada durante el período presidencial de Ricardo Lagos.

A partir de una primera sistematización, se procuró ordenarlas en dos grandes vertientes: una que fuera demostrativa de un proceso de reducción de la criminalización y otra que fuera signo evidente del aumento de la misma, y a partir de dicho análisis, concluir la existencia o no de procesos históricos con un determinado sesgo político-criminal que tuviera consagración en las mutaciones legales de raigambre penal sustantivo estudiadas. Además, un segundo ejercicio de ordenación buscó establecer si es que era posible relacionar los cambios normativos, de sesgo punitivo o de morigeración penal, con un determinado contexto histórico, tomando como referencia los períodos presidenciales de los gobiernos democráticos que se dan desde el año 1990, hasta 2006. Por último, una tercera operación agrupó la normativa de forma tal que permitiera conocer a qué tipo de materias se referían dichos preceptos, y en el caso de la agrupación criminalizadora, a qué bienes jurídicos se buscaba dar protección.

Así, con este caudal normativo y teniendo como sustento el planteamiento del profesor español Jesús María Silva Sánchez detallado en su obra La expansión del Derecho Penal, se buscó dar respuesta a si las evaluaciones constatadas por este autor en la España de los noventa eran posibles de extrapolar a nuestra realidad nacional.

\footnotetext{
${ }^{1}$ Silva Sánchez, Jesús-María: La expansión del Derecho Penal. Aspecto de la política criminal en las sociedades postindustriales, $2^{\mathrm{a}}$ edición, Editorial Civitas, 2001.
} 
Nilo - Normativa sustantivo-penal durante los gobiernos de Aylwin, Frei y Lagos...

En definitiva, lo que se ha querido resolver es si el Derecho Penal chileno ha entrado en una dinámica de "expansión", considerando que Chile no ha tenido propiamente una sociedad industrial y que sigue siendo un país en vías de desarrollo, o si, por contra, nos demuestra ser un proceso que no alcanza por su magnitud a ser tal, y que puede ser calificado sólo de "intensificación", es decir, un fenómeno que reúne características comunes con el análisis realizado por Silva Sánchez, pero que se diferencia de aquel en puntos centrales. Además, en ese mismo marco, se ha querido constatar si es posible atisbar la presencia del fenómeno de "administrativización" del Derecho Penal nacional, y por último, determinar su calificación, como un Derecho Penal de única, doble o tercera velocidad, según las categorías utilizadas por el autor español.

\section{Fenomenología de leyes}

\subsection{Reduccionismo penal y criminalización}

Enunciado el objetivo de la presente investigación y sus desafíos, se decidió, primeramente, dividir en dos grupos las 102 leyes objeto de estudio: a) el primero, que denominaremos "reduccionista" o de la descriminalización, en que se hará mención a la(s) hipótesis concreta(s) que califica(n) a una normativa para ser inclusa en este grupo, como es cuando suprime delitos o reduce el ámbito de lo punible, y en este último caso, cuando establece eximentes, indultos o toda otra forma de exención especial, o cuando se precisa el alcance de figuras antiguas más amplias; y b) el segundo grupo, que denominaremos "expansivo" o de aumento en la criminalización, al que se pertenecerá cuando una ley incorpore nuevas figuras o tipos penales, cuando adecue figuras antiguas a la realidad actual, o amplíe de cualquier manera las sanciones, y por último, cuando se extienda el ámbito de lo punible, con modificaciones penológicas que tiendan a una mayor gravosidad de la sanción, sea con el castigo de cómplices como autores o de formas incompletas de iter criminis penalizadas como figuras consumadas, o cuando exista la expresa tipificación de actos preparatorios como ilicitudes autónomas.

El conjunto de normas y su detalle se incluye infra en apartado independiente anexado a este artículo, y su análisis ha permitido sistematizar las leyes de la forma que sigue: un primer grupo, denominado "reduccionista" o de "descriminalización", que contiene aquellas leyes que conceden indultos generales o amnistías ${ }^{2}$, conceden beneficios u ordenan eliminación de antecedentes penales, las que establecen normas que precisan el alcance de figuras antiguas más amplias $^{4}$, suprimen tipos penales ${ }^{5}$ o determinadas sanciones ${ }^{6}$, establecen causales

\footnotetext{
2 Véase anexo $\mathrm{N}^{\circ} 1$.

${ }^{3}$ Véase anexo $\mathrm{N}^{\circ} 2$.

${ }^{4}$ Véase anexo $\mathrm{N}^{\circ} 3$.

${ }^{5}$ Véase anexo $\mathrm{N}^{\circ} 4$

${ }^{6}$ Véase anexo $\mathrm{N}^{\circ} 5$.
} 
de atipicidad ${ }^{7}$, morigeran o limitan la pena ${ }^{8}$, contemplan atenuantes o amplían su contenido ${ }^{9}$, establecen el alcance de causales de extinción de responsabilidad penal ${ }^{10} \mathrm{o}$ toda forma de exención especial. ${ }^{11}$

Forman parte del segundo grupo, llamado de la expansión o de aumento en la criminalización, aquellas que consisten en la creación de tipos penales ${ }^{12}$, adecuación de figuras antiguas a la realidad actual ${ }^{13}$, o ampliación de cualquier manera de las sanciones ${ }^{14}$, regulación de situaciones sui generis que impliquen rigurosidad en la penalización ${ }^{15} \mathrm{y}$, por último, cuando se extienda el ámbito de lo punible $^{16}$, con modificaciones en la tipicidad de las conductas ${ }^{17}$, enmiendas penológicas que tiendan a una mayor gravosidad de la sanción ${ }^{18}$ o que impida la aplicación de ciertas morigerantes ${ }^{19}$, incluya agravantes o las describa de una forma novedosa y que ello represente un mayor rigor punitivo ${ }^{20}$, además del castigo de cómplices u otras formas de participación como autores o de formas incompletas de iter criminis penalizadas como figuras consumadas ${ }^{21}$, con la existencia de presunciones legales de autoría ${ }^{22}$, o aun más, cuando exista la expresa tipificación de actos preparatorios como ilicitudes autónomas. ${ }^{23}$

\subsubsection{Contexto histórico en que se dan los fenómenos de morigeración penal y criminalización en los gobiernos de Aylwin, Frei y Lagos}

Durante el período presidencial de Patricio Aylwin Azócar, que va desde el 11 de marzo de 1990 al 11 de marzo de 1994, gran parte de la normativa relativa a su periodo calza con la agrupación de "reduccionismo" o de morigeración penal, lo que tiene ver con el momento histórico que se vive durante su gestión, esto es, de transición desde un régimen autoritario a uno democrático. Pues bien, se busca atenuar o eliminar los efectos de una legislación autoritaria y hacerla compatible con el nuevo régimen; y otra parte de aquella normativa, persigue eliminar todo vestigio de elementos desestabilizadores del nuevo sistema -grupos extremistas

\footnotetext{
7 Véase anexo $\mathrm{N}^{\circ} 6$.

8 Véase anexo $\mathrm{N}^{\circ} 7$.

9 Véase anexo $\mathrm{N}^{\circ} 8$.

${ }^{10}$ Véase anexo $\mathrm{N}^{\circ} 9$.

11 Véase anexo $\mathrm{N}^{\circ} 10$.

12 Véase anexo $\mathrm{N}^{\circ} 11$.

13 Véase anexo $\mathrm{N}^{\circ} 12$.

14 Véase anexo $\mathrm{N}^{\circ} 13$.

15 Véase anexo $\mathrm{N}^{\circ} 14$.

16 Véase anexo $\mathrm{N}^{\circ} 15$.

17 Véase anexo $\mathrm{N}^{\circ} 16$.

18 Véase anexo $\mathrm{N}^{\circ} 17$.

${ }^{19}$ Véase anexo $\mathrm{N}^{\circ} 18$.

20 Véase anexo $\mathrm{N}^{\circ} 19$.

21 Véase anexo $\mathrm{N}^{\circ} 20$.

22 Véase anexo $\mathrm{N}^{\circ} 21$.

${ }^{23}$ Véase anexo $\mathrm{N}^{\circ} 22$.
} 
Nilo - Normativa sustantivo-penal durante los gobiernos de Aylwin, Frei y Lagos...

que lucharon contra la dictadura militar-, optándose por reinsertarlos a la sociedad. Así, es expresión de lo primero la modificación a la ley $\mathrm{N}^{\circ} 18.314$, que determina conductas terroristas y fija su penalidad, plasmada en la ley $\mathrm{N}^{\circ} 19.127$, que se publica el 24.01.1991, y la ley $\mathrm{N}^{\circ} 19.048$, publicada 13.02.1991, que deroga la ley $\mathrm{N}^{\circ} 18.662$ sobre el efecto de la declaración de organizaciones y asociaciones contrarias al ordenamiento institucional de la República. Por su parte, ejemplo de lo segundo, es la ley $\mathrm{N}^{\circ}$ 18. 978, publicada el 14.05.1990, y la ley $\mathrm{N}^{\circ} 19.172$, publicada el 04.11.1992.

Por el contrario, es expresión despenalizadora en materia de delitos sexuales la ley $\mathrm{N}^{\circ}$ 19.221, publicada el 01.06.1993, que establece la mayoría de edad a los 18 años y que sustituye en los artículos 359, 363 y 366 del Código Penal la palabra "veinte" por "dieciocho", con lo cual se amplía el margen de edad en que se considera a una persona con capacidad de autodeterminación sexual, limitándose por ende, la punición de conductas.

Finalmente, en el período analizado cabe destacar la primera norma que plantea la derogación de la pena de muerte [ley $\mathrm{N}^{\circ} 19.029$, publicada el 23.01.1991] y en materia del catálogo de ilicitudes afectatorias de la propiedad la ley $\mathrm{N}^{\circ}$ 19.114, que introduce en las modificaciones a la ley $\mathrm{N}^{\circ} 19.047$, una expresión de despenalización al crear una nueva hipótesis de causal de justificación de legítima defensa del artículo 10, $\mathrm{N}^{\circ} 6$ del Código Penal. Así, las leyes que denotan un esfuerzo criminalizador son escasas, y aparecen como dignos de destacar sólo dos ejemplos: ley $\mathrm{N}^{\circ}$ 19.077, publicada el 14.08.1991, que introduce modificaciones al Código de Procedimiento Penal en lo relativo a los delitos de robo y hurto, con la inclusión de la figura típica de obstrucción a la justicia, y la ley $\mathrm{N}^{\circ}$ 19.241, publicada el 28.08.1993, que modifica artículos del Código Penal, y aumenta las penas en el delito de secuestro y en el de sustracción de menores, de los artículos 141 y 142 respectivamente.

Sin perjuicio del marcado tinte de la etapa anterior, el período del presidente Eduardo Frei Ruiz-Tagle es expresión, en una primera fase, también del mismo fenómeno de morigeración penal, referido para su caso al objetivo de asentar los principios democráticos, con un influjo directo sobre la normativa sustantivo-penal que se dicta y aquella que se deja de aplicar, por su incompatibilidad con el nuevo ideario político. Ejemplo de lo anterior es la ley $\mathrm{N}^{\circ}$ 19.313, publicada el 21.07.1994, en que se derogan disposiciones que se indican de la ley $\mathrm{N}^{\circ} 11.625$, sobre estados antisociales y medidas de seguridad, y la normativa $\mathrm{N}^{\circ}$ 19.567, publicada el 01.07.1998, que deroga los delitos asociados a los denominados estados antisociales de vagancia y mendicidad.

Este esfuerzo que llamaremos de "concordancia", pues lo que busca es lograr la coherencia de un Derecho Penal liberal con los principios inspiradores de la democracia naciente, y que adscribe a la descriminalización como fenómeno, termina aparentemente con la dictación de la ley $\mathrm{N}^{\circ} 19.325$, publicada el 27.08.1994, de violencia intrafamiliar, a la que sigue temporalmente, la ley $\mathrm{N}^{\circ}$ 
19.327, publicada el 31.08.1994, que regula los delitos cometidos con ocasión de espectáculos de fútbol profesional, y a las anteriores, que son sin duda de carácter criminalizador, sigue la ley ley $\mathrm{N}^{\circ} 19.335$, publicada el 23.09.1994, que deroga los artículos 375 al 381 del Código Penal, sobre adulterio, la que es de evidente carácter despenalizador. Así, se trata este período de una primera fase que es ambivalente, pues a lo anterior siguen leyes de marcado sesgo incriminador, como la ley $\mathrm{N}^{\circ} 19.366$, publicada el 30.01.1995, sobre tráfico ilícito de estupefacientes, la ley $\mathrm{N}^{\circ}$ 19.413, que introduce modificaciones al Código Penal en materia de delito de receptación, y la ley $\mathrm{N}^{\circ} 19.449$, del 08.03.1996, que aumenta la pena del delito de robo en lugar habitado.

Sin embargo, el punto de inflexión se sitúa en la ley $\mathrm{N}^{\circ}$ 19.450, publicada el 18.03.1996, en que se sustituye la escala de multas y se modifica el Código Penal y otros cuerpos legales, ampliándose el margen punitivo de las faltas, a ilicitudes como la sustracción de funcionario público que tengan a cargo caudales públicos o particulares, en el delito de hurto, de estafa y de incendio, cuando los montos malversados, defraudados o sustraídos no excedan las cinco unidades tributarias mensuales -lo que lleva a variar las cuantías respectivas para la configuración de los simples delitos-, todo lo cual representa una clara manifestación de morigeración sancionatoria. Sin embargo, la normativa destacada jamás entró en vigencia, primero debido a que la ley $\mathrm{N}^{\circ} 19.456$, publicada el 16.05.1996, posterga su entrada en vigencia para luego definitivamente, por ley $\mathrm{N}^{0} 19.501$, publicada el 15.05.1997, la primigenia ley $\mathrm{N}^{\circ} 19.450$, ser sometida a profundas y esenciales enmiendas que alteran su sentido y alcance original. Lo anterior resulta palmario, cuando, por ejemplo, en los artículos 233, 446, 467 y 477 del Código Penal, se modifica la escala de sanciones y se disminuye con ello las cuantías o montos requeridos a ser defraudados, sustraídos u apropiados, lo que lleva a la ampliación en la punición de los simples delitos y disminuye el terreno de las faltas.

Es a partir de esta enmienda legislativa que fijamos el camino sin regreso de la rigidización punitiva, el que alcanza hasta la finalización del período de Eduardo Frei y comprende todo el mandato del presidente Ricardo Lagos [11 de marzo de 2000 al 11 de marzo de 2006]. Así, en el saldo del período correspondiente al presidente Frei, se incorpora un importante número de normas de las que se destaca la ley $\mathrm{N}^{\circ}$ 19.617, publicada el 12.07.1999, que modifica el Código Penal, el Código de Procedimiento Penal y otros cuerpos legales en materias relativas al delito de violación e incluye el delito de sodomía, y además la ley $\mathrm{N}^{\circ}$ 19.645, publicada el 11.12.1999, que modifica disposiciones del Código Penal que sancionan delitos de corrupción. El cariz de las leyes enunciadas sella la impronta normativa del período antes aludido y otorga relevancia a la protección de ciertos bienes jurídicos, con la sanción de conductas que hasta ese entonces eran impunes o con la agravación de sanciones ya existentes.

Por su parte, en el caso del mandato del presidente Lagos, a pesar del sello criminalizador característico del período, se dan expresiones contrasistémicas de 
Nilo - Normativa sustantivo-penal durante los gobiernos de Aylwin, Frei y Lagos...

morigeración penal, asociadas esencialmente a decisiones de política criminal y al problema de hacinamiento carcelario. En efecto, son expresiones de aquello la ley $\mathrm{N}^{\circ}$ 19.736, publicada el 19.07.2001, sobre indulto general, con motivo del jubileo 2000; también la ley $\mathrm{N}^{\circ} 19.965$, publicada 25.08.2004, que concede beneficios a condenados, y la ley $\mathrm{N}^{\circ} 19.856$, publicada el 04.02.2003, que crea un sistema de reinserción social de los condenados sobre la base de la observación de buena conducta. Otra expresión relevante, ya no en el plano anteriormente aludido, fluye del ámbito de la política económica, con la ley $\mathrm{N}^{\circ}$ 19.911, publicada el 14.11.2003, que crea el Tribunal de Defensa de la Libre Competencia, en cuanto deroga ilicitudes asociadas a conductas atentatorias a la libre competencia dentro del país, ley que tiene como objetivo reactivar el aparato productivo nacional, mermado a consecuencia de los graves efectos de la denominada "crisis asiática". Sin embargo, la decisión anterior, en nuestra opinión, es expresión además de la preponderancia que se otorga al logro de la recuperación económica-como objetivo central y primordial dentro del Estado- por sobre o a costa de los llamados "derechos de los consumidores".

Por último, ya en la lógica del endurecimiento penal, se pueden constatar en el gobierno de Lagos distintos fenómenos asociados primero a una hipervaloración de ciertos bienes jurídicos, y segundo, a la absorción de tipos penales afincados derechamente en la denominada "criminalidad organizada transnacional". Demostración de esto último, son la ley $\mathrm{N}^{\circ} 19.829$, publicada el 08.10.2002, en cuanto modifica el Código Penal respecto del delito de cohecho, en el nuevo artículo 250 bis a), denominado "cohecho transnacional"; la Ley $\mathrm{N}^{\circ}$ 19.906, del 13.11.2003, que modifica la ley $\mathrm{N}^{\circ} 18.314$ sobre conductas terroristas, en orden a sancionar más eficazmente la financiación del terrorismo; la ley $\mathrm{N}^{\circ}$ 19.913, publicada el 18.12.2003, en cuanto crea la Unidad de Análisis Financiero; y la ley $\mathrm{N}^{\circ}$ 20.000, del 16.02.2005, sobre tráfico de drogas.

Por otro lado, en cuanto a la supervaloración y preponderancia que se otorga a determinados bienes jurídicos, podrá apreciarse la ley $\mathrm{N}^{\circ}$ 19.927, publicada el 14.01.2004, en cuanto modifica el Código Penal en materia de delitos de pornografía infantil e incorpora nuevos tipos penales, como el del artículo 365 bis del compendio sustantivo penal; la ley $\mathrm{N}^{\circ}$ 19.975, del 05.10.2004, que modifica el Código Penal en materia de uso y porte de armas, e incorpora como nuevo tipo penal el porte de armas cortantes o punzantes en determinados lugares; y por último, la ley $\mathrm{N}^{\circ} 20.066$, publicada el 07.10.2005, sobre violencia intrafamiliar. 


\subsubsection{Sobre qué materia versan las leyes sustantivo-penales}

\section{a) En la agrupación de leyes sustantivo-penales adscritas a un "reduccionismo penal"}

A partir de la sistematización realizada pareció útil reconocer para cada uno de los mencionados grupos, de incriminación o de morigeración penal, sobre qué materia versaban tales cuerpos legislativos, o dicho de otra forma, si era posible descubrir un contenido común que permitiera graficar su objetivo o finalidad. Así, utilizando la fenomenología central de este estudio, dentro del primer grupo, llamado "reduccionista", pareció clara la existencia de normativa que buscaba lograr el asentamiento del sistema democrático naciente, relacionada con la seguridad interior del Estado y que tenía que ver con un momento histórico determinado, específicamente en leyes originadas en el seno de la transición desde un gobierno autoritario a uno de carácter democrático. De esta forma, la legislación del período se caracteriza por discurrir, paulatinamente, desde la morigeración de los efectos de las normas surgidas en el gobierno de facto hacia la derogación completa y final de cierto articulado, el que incluso se manifiesta en decisiones de indulto para actos delictuales que acontecen en los primeros años de la democracia. Así pues, a modo de ejemplificación, una expresión de tal transición, entre diversos regímenes políticos, puede encontrarse en el artículo $11^{\circ}$ de la ley $\mathrm{N}^{\circ}$ 19.047, publicada el 14.02.1991, que para aplicar la prescripción de la pena o de la acción penal, previene que no se entienden ausentes del territorio nacional los que hubieren estado sujetos a prohibición o impedimento de ingreso al país, y de tal forma se atiende a una realidad como fue el exilio que padecieron muchos compatriotas. De esta manera, lo antes dicho busca, en cuanto a la primera hipótesis, eliminar la normativa incompatible con un ordenamiento jurídico democrático e, incluso, adecuar dichas normas a los principios del Derecho Penal clásico, y en cuanto a la segunda situación, su objetivo se desarrolla en torno a dar solidez y estabilidad al nuevo régimen democrático. Aquí lo que en verdad existe es una decisión de Estado para procurar la desarticulación de los grupos terroristas, que ya a partir del año 1990 pierden sentido y que incluso llevan a más de alguno de sus miembros a mutar el móvil político inicial de su actividad a uno que tiene que ver con la comisión de hechos delictuosos comunes. Es por la razón anterior que a esas personas se les procura reinsertar en sociedad con la concesión de una nueva oportunidad, y de "sumarlos" al proceso, no "restarlos".

Constituye expresión de lo anterior la actividad legislativa que se plasma en ciertas leyes -que son fruto de acuerdos políticos entre gobierno y oposición- en que se crean indultos, como con la ley $\mathrm{N}^{\circ} 18.978$, publicada el 14.05.1990, que concede indulto general de rebaja de sanción; la ley $\mathrm{N}^{\circ}$ 19.172, del 04.11.1992, sobre arrepentimiento eficaz, que hace procedente el beneficio de libertad vigilada para aquellos que abandonen las organizaciones terroristas y confiesen todos los delitos en que hayan participado, y también la ley $\mathrm{N}^{\circ}$ 19.962, publicada el 25.08.2004, que dispone la eliminación de ciertas anotaciones prontuariales, 
Nilo - Normativa sustantivo-penal durante los gobiernos de Aylwin, Frei y Lagos...

referidas a condenas impuestas por Tribunales Militares u Ordinarios, por hechos acaecidos entre el 11 de septiembre de 1973 y el 10 de marzo de 1990 y sancionados en la Ley de Seguridad del Estado; ley $\mathrm{N}^{\circ} 17.798$, sobre control de armas y ley $\mathrm{N}^{\circ} 18.314$, que determina conductas terroristas y fija su penalidad, o en los decretos leyes $\mathrm{N}^{\mathrm{o}} 77$, de 1973, o $\mathrm{N}^{\mathrm{o}} 3.627$, de 1981.

Por otra parte, son manifestaciones o expresiones de la búsqueda de la eliminación de legislación que se estima incompatible con un ordenamiento jurídico democrático la ley $\mathrm{N}^{\circ}$ 19.027, publicada el 24.01.1991, que modifica ley $\mathrm{N}^{\circ}$ 18.314, que determina conductas terroristas y fija su penalidad; la ley $\mathrm{N}^{\circ}$ 19.048, del 13.02.1991, texto que modifica leyes $\mathrm{N}^{\circ} \mathrm{s} 18.015,18.150,18.662$, 18.313 y 16.643 sobre abusos de publicidad, y específicamente en cuanto a esta última, muta su artículo 21 con relación a los delitos de injuria o calumnia, cometidos por medios de difusión masiva, con la inclusión de hipótesis de hecho que no constituyen injurias y que conforman apreciaciones que se formulan en artículos de crítica, política, literaria, histórica, artística, científica, técnica y deportiva. Además, se encuentra la ley $\mathrm{N}^{\circ}$ 19.313, del 21.07.1994, en que se derogan las disposiciones que se indican de la ley $\mathrm{N}^{\circ} 11.625$, sobre estados antisociales y medidas de seguridad; la ley $\mathrm{N}^{\circ}$ 19.567, publicada el 01.07.1998, que modifica el Código de Procedimiento Penal y el Código Penal en lo relativo a la detención, y que dicta normas de protección a los derechos del ciudadano, y deroga los delitos asociados a los denominados estados antisociales de vagancia y mendicidad; por último, se incluye a la ley $\mathrm{N}^{\circ}$ 19.733, publicada el 04.06.2001, sobre libertad de opinión e información y ejercicio del periodismo. En definitiva, la materia regulada dice relación con el ejercicio de una garantía constitucional como la libertad de opinión, y ella como resguardo del pluralismo político, todo lo cual resulta ser el fundamento de un Estado democrático de derecho, como es el que se intenta construir en el Chile de la década de los 90.

Otro tinte teleológico poseen aquellas normas que incorporan una decisión de política criminal de los gobiernos de turno, en cuanto a dar preeminencia a la finalidad preventivo-especial de la sanción, que esconde una de las problemáticas que son consecuencia de la rigidización o endurecimiento penal, esto es, el hacinamiento carcelario. En efecto, demostraciones de lo anterior son las leyes que conceden beneficios e indultos, como la ley $\mathrm{N}^{\circ} 19.736$, publicada el 19.07.2001, sobre indulto general, con motivo del Jubileo 2000, o la ley $\mathrm{N}^{\circ} 19.856$, del 04.02.2003, que crea un sistema de reinserción social de los condenados sobre la base de la observación de buena conducta.

Además, otra materia que se incluye en este grupo de "reduccionismo punitivo", por representar incentivos de raigambre sustantivo-penal y herramientas de persecución criminal, son las normas que regulan la entrega de armas prohibidas, o que no se encuentran debidamente inscritas, de manos de particulares a la autoridad competente, como en la ley $\mathrm{N}^{\circ} 19.047$, publicada el 14.02.1991 y en casos como el de la ley $\mathrm{N}^{\circ} 20.014$, de 13.05.2005, que modifica la ley $\mathrm{N}^{\mathrm{o}} 17.798$, sobre control de armas, con la inclusión del artículo $14 \mathrm{c}$ ), en 
cuanto a que constituye una circunstancia eximente de responsabilidad "...la entrega voluntaria de las armas o elementos a las autoridades...".

Otro orden de materias reguladas en este grupo es el tráfico de drogas, con la incorporación de causales de justificación que liberan de responsabilidad criminal a ciertos agentes, en ciertas circunstancias. Se encuentra primero, la ley $\mathrm{N}^{\circ} 19.366$, y luego su sucesora, $\mathrm{N}^{\circ} 20.000$, con la exención de responsabilidad penal de los agentes encubiertos o reveladores que desbaratan con su actuar una actividad propia del comercio de sustancias ilícitas. Asimismo, pueden expresarse estas formas de cooperación con la investigación como atenuantes de responsabilidad, como en la ley $\mathrm{N}^{\circ} 19.806$, publicada el 31.05.2002, que modifica la ley $\mathrm{N}^{\circ} 19.366$, y que contempla en el artículo 33 la institución de la cooperación eficaz hacia al esclarecimiento de los hechos investigados, al igual que en la ley $\mathrm{N}^{\circ}$ 20.000, sobre tráfico de drogas, en su artículo 22, donde se regula la misma circunstancia minorante de responsabilidad.

Además, encontramos ilicitudes de naturaleza patrimonial, sea este peculio privado o fiscal. Por un lado, se entregan herramientas de persecución del delito, como la ley $\mathrm{N}^{\circ}$ 19.164, publicada el 02.09.1992, que incorpora en el Código Penal, la legítima defensa privilegiada, que en sí es expresión de "reduccionismo penal" por ser una nueva hipótesis de causal de justificación, y también, se incluye como base de solución anticipada del conflicto penal la declaración de inexistencia de un tipo penal o la incorporación de una atenuación a la responsabilidad criminal, cuando se dan ciertos supuestos: como expresión de lo primero, la ley $\mathrm{N}^{\circ} 19.806$, del 31.05.2002, que modificó el DFL No 707 de 1982 del Ministerio de Justicia, que fija el texto refundido, coordinado y sistematizado de la ley sobre cuentas corrientes bancarias y cheques, y que en su artículo 22 previene que: "El pago del cheque, los intereses corrientes y las costas judiciales, si las hubiere, constituirá causal de sobreseimiento definitivo,..."; y para la segunda cuestión, la ley $\mathrm{N}^{\circ}$ 19.738, publicada el 19.06.2001, que establece normas para combatir la evasión tributaria, al modificar el inciso final del artículo 176 de la Ordenanza de Aduanas, contenida en el DFL N ${ }^{\circ} 2$ del año 1997, que expresa: "En estos delitos, deberán considerarse las siguientes circunstancias atenuantes calificadas siempre que ocurran antes del acto de fiscalización: a) la entrega voluntaria a la Aduana de las mercancías ilegalmente internadas al país; y b) el pago voluntario de los derechos e impuestos de las mercancías cuestionadas".

Otra materia normada en este grupo de morigeración penal se relaciona con la eliminación de la discriminación de género, cuando la ley $\mathrm{N}^{\circ} 19.335$, publicada el 23.09.1994, deroga los artículos 375 al 381 del Código Penal con relación al adulterio, y también cuando integra modificaciones de orden civil con consecuencia en lo penal, en ley $\mathrm{N}^{\circ} 19.947$, del 17.05.2004, que deroga desde el artículo 385 al 387 del Código Penal.

Por último, una materia que tuvo consagración en varias leyes, y que representa una humanización de las penas dentro de un Estado democrático, fue 
Nilo - Normativa sustantivo-penal durante los gobiernos de Aylwin, Frei y Lagos...

lo relativo a la derogación de la pena de muerte, la que tuvo expresión en la ley $\mathrm{N}^{\circ}$ 19.029, publicada el 23.01.1991, también en la ley $\mathrm{N}^{\circ} 19.734$, del 05.06.2001, y por último, en la ley $\mathrm{N}^{\circ}$ 19.804, del 24.05.2002.

\section{b) En la agrupación criminalizadora. Materia sobre la cual versan dichas leyes sustantivo-penales y bien jurídico tutelado}

Un segundo punto de vista, pero ahora en el grupo de criminalización, lleva a sistematizar las leyes penales según la materia regulada y el bien jurídico que se tutela; en un primer orden, se encuentra la temática sexual, particularmente, aquella que resguarda en sus descripciones típicas el bien jurídico libertad, indemnidad u honestidad sexual, siendo palmaria su importancia, dada la entidad de las transformaciones legales producidas. Constituyen manifestaciones del fenómeno anterior la ley $\mathrm{N}^{\circ}$ 19.409, que agrega el artículo 367 bis al Código Penal y tipifica la trata de personas, y la ley $\mathrm{N}^{\circ} 19.617$, publicada el 12.07.1999. Además, específicamente en el orden de la esfera de protección sexual, y en relación directa con el resguardo a la indemnidad sexual de los menores de edad, se reguló el fenómeno ascendente de la pornografía infantil, todo lo cual tiene expresión, en la ley $\mathrm{N}^{\circ} 19.927$.

Una segunda materia de regulación se refiere a delitos de carácter patrimonial, específicamente, los que se relacionan con el bien jurídico propiedad, y aquellas ilicitudes que se componen de un objeto de protección mixto y que suman a lo patrimonial la afectación real o potencial de la seguridad e integridad de las personas, como en el robo con intimidación o en el robo en lugar habitado. Así, es prolífica la regulación de incriminación en este tipo de delitos, porque son los que ocurren más frecuentemente ${ }^{24} \mathrm{y}$ dan pie a la generación de una "legislación reactiva" al problema de escalada delincuencial, todo lo cual lleva a tener insignes ejemplos normativos, como la ley $\mathrm{N}^{\circ}$ 19.077, publicada el día 14.08.1991, que introduce modificaciones al Código de Procedimiento Penal en lo relativo a los delitos de robo y hurto, con la inclusión de la figura típica de obstrucción a la justicia; la ley $\mathrm{N}^{\circ}$ 19.413, publicada el 20.09.1995, en cuanto introduce modificaciones al Código Penal, con una nueva descripción del delito de receptación en el artículo 456 bis a) del Código Penal; ley $\mathrm{N}^{\circ}$ 19.449, del 08.03.1996, en cuanto introduce modificación a la sanción corporal del delito de robo en lugar habitado, aumentándola; la ley $\mathrm{N}^{\circ}$ 19.501, publicada el 15.05.1997, normativa que introduce modificaciones a la ley $\mathrm{N}^{\circ} 19.450$, de claro tinte descriminalizador, para que ella mute su inicial sesgo; ley $\mathrm{N}^{\circ} 19.950$, del 05.06.2004, que aumenta sanciones a hurtos y tipifica de forma independiente la falta de hurto, en el artículo 494 bis del Código Penal ${ }^{25}$; y por último, la ley $\mathrm{N}^{\circ}$

\footnotetext{
${ }^{24}$ Fuente: Defensoría Penal Pública, Memoria Anual 2007, p. 30. Indica que los delitos contra la propiedad constituyen el $34,9 \%$ de los delitos ingresados a la Defensoría, cuyo desglose es el siguiente: robos $7,3 \%$, robos no violentos $6,7 \%$, hurtos $13,8 \%$ y otros delitos contra la propiedad $7,1 \%$.

${ }^{25}$ En Chile, en contra de esta penalización, Mera, Jorge, Hurto y Robo, Santiago, Editorial Conosur, 1995, pp. 63-66, quien propugna la despenalización de un amplio sector de la bagatela, en
} 
20.090, publicada el 11.01.2006, que sanciona con mayor vigor el delito de abigeato.

Otro tópico incorporado es la violencia intrafamiliar, que requiere atender a la relación especial de los implicados en la situación de conflicto, la naturaleza violenta de dichos actos y la intensidad de los mismos ${ }^{26}$, de modo de tratarse de un fenómeno que afecta la paz familiar; pero más allá de lo anterior, el contexto circunstancial de este tipo de actos, favorece la existencia del denominado fenómeno de "violencia de género", y en este sentido, el Derecho Penal propende a la protección de la más débil [mujer] frente al más fuerte [hombre], todo lo cual ha llevado, entre otras cosas, a que el discurso feminista oficial pase de la denuncia de la violencia doméstica a centrarse en la violencia de género, atribuyendo una función al derecho, de instrumento adecuado para proteger, aumentar la igualdad y dotar de mayor poder a la mujeres. ${ }^{27}$ Son ejemplos de lo anterior la ley $\mathrm{N}^{\circ}$ 19.325 de violencia intrafamiliar, publicada el día 27.08.1994; la ley $\mathrm{N}^{\circ} 19.968$, del 30.08.2004, que en su artículo 84 establece la obligación de denunciar los hechos que pudieren constituir violencia intrafamiliar para las personas designadas en el artículo 175 del Código Procesal Penal, y su incumplimiento lleva aparejada como sanción la pena prevista en el artículo 494 del compendio sustantivo penal; y la ley $\mathrm{N}^{\circ}$ 20.066, del 07.10.2005, que establece la nueva regulación de esta materia.

También se regula por el legislador penal -otorgándole una gran relevancia- el poder o debido control que se tenga sobre las armas de fuego dentro de la sociedad. En efecto, se refiere a aquellas armas que sean susceptibles de ser mantenidas en poder de particulares de forma de llevar un catastro de las mismas, a fin de evitar que formen parte del mercado negro, de la autotutela privada en la lucha contra la delincuencia, y en definitiva, que caigan en manos inexpertas o en poder de inescrupulosos, que pueden ser los mismos delincuentes. En definitiva, el bien jurídico tutelado será la seguridad, concepto que se conecta con aquellas conductas calificadas como atentados contra la seguridad del Estado, sus autoridades, servicios de utilidad pública, instalaciones de aeronavegación, etc., específicamente la peligrosidad manifiesta que encierra tanto la posesión como el empleo de elementos que establece la ley". 28 Por lo tanto, existe una especial peligrosidad que reviste para las víctimas de cualquier delito el que los hechores sean portadores de armas de cualquier tipo, por el mayor riesgo para la integridad física que ello conlleva y, además, por la renuncia tácita que lleva el admitir que particulares tengan en su poder armas de fuego no regularizadas o prohibidas, cuando es función del Estado su posesión monopólica, tanto para la seguridad interna como externa. Se cuenta, entre otras, con la ley $\mathrm{N}^{\circ} 19.975$, publicada el

particular en los delitos de hurto, en que, "por el poco valor de la cosa, el problema sólo debiera quedar entregado a las vías civiles y administrativas".

${ }^{26}$ Aguirre, Patricia: Ley de Violencia Intrafamiliar, Análisis Jurídico, Santiago, Conosur, 1999, p.46.

${ }^{27}$ Larrauri, Elena: Criminología Crítica y Violencia de Género, Madrid, Trotta, 2007, pp. 18-19.

${ }^{28}$ Cea, Sergio; Morales, Patricio: Control de Armas, Manual de Aplicación de la ley $N^{\circ} 17.798$ y su

Reglamento, $3^{\circ}$ edición, Santiago, Legal Publishing, 2009, p. 9. 
Nilo - Normativa sustantivo-penal durante los gobiernos de Aylwin, Frei y Lagos...

05.10.2004, normativa que modifica el Código Penal en materia de uso y porte de armas; la ley $\mathrm{N}^{\circ} 20.014$, publicada el 13.05.2005, que introduce modificaciones en la ley $\mathrm{N}^{\circ} 17.798$, sobre control de armas, e incluye un nuevo artículo $9^{\circ}$ a) y 17 a); y la ley $\mathrm{N}^{\circ} 20.061$, del 10.09.2005.

Otro tópico regulado es la seguridad pública, que se enfrenta con normativa que busca el logro de la paz social. Ejemplo de lo anterior son la ley 19.327, publicada el 31.08.1994, que regula la comisión de delitos con ocasión de espectáculos de fútbol profesional; la ley $\mathrm{N}^{\circ} 20.064$, del 29.09.2005, que aumenta las penas en los casos de delitos de maltrato de obra a Carabineros y modifica el artículo 17 ter, del DL N².460, de 1979, de la Ley Orgánica de la Policía de Investigaciones de Chile; y finalmente, la ley $\mathrm{N}^{\circ}$ 20.084, publicada el día 07.12.2005, que establece un sistema de responsabilidad de los adolescentes por infracciones a la ley penal, y que responde al aumento del fenómeno delincuencial juvenil.

Sobre otro punto, el fenómeno de la delincuencia organizada y su financiamiento se ataca a través de la legislación que combate el delito de tráfico de drogas, al que se relaciona el lavado de dinero, cuya expresión normativa se da en la ley $\mathrm{N}^{\circ} 19.366$, y en la ley $\mathrm{N}^{\circ} 20.000$, y además, con la ley $\mathrm{N}^{\circ} 19.906$, que modifica la ley $\mathrm{N}^{\circ} 18.314$ sobre conductas terroristas, en orden a sancionar más eficazmente el financiamiento del terrorismo. Se une además a la anterior normativa aquella que constituye un instrumento destinado a la pesquisa de esta esfera delincuencial, con la incorporación de articulado de carácter sustantivopenal, en la ley $\mathrm{N}^{\circ}$ 19.913, publicada el 18.12.2003, que crea la unidad de análisis financiero.

Sin embargo, más allá de la actividad financiera ligada a la actividad ilícita, el objeto jurídico de protección en el caso del delito de tráfico de sustancias ilícitas seguirá siendo la salud pública, esto es, la salud física y mental de aquel sector de la colectividad que pueda verse afectado por el efecto nocivo de las sustancias prohibidas $^{29}$, y por otra parte, en el caso de los delitos terroristas, el objeto de tutela será el mismo sistema democrático instituido, con su correspondiente estructura jurídico-institucional, en la cual el grupo terrorista no cree y desea destruir.

Otra materia, que hemos denominado de protección y respeto a determinadas garantías individuales, se contienen en la ley $\mathrm{N}^{0} 19.423$, publicada el 20.11.1995, normativa en que se agregan disposiciones en el Código Penal, en lo relativo a delitos contra el respeto y protección a la vida privada y pública de la persona y su familia, con los nuevos artículos 161 a) y 161 b) del texto sustantivo penal y que protegen como objeto jurídico la intimidad de cada persona. Además, se encuentra la ley $\mathrm{N}^{\circ}$ 19.567, publicada el 01.07.1998, que, en lo relativo a la

\footnotetext{
${ }^{29}$ Politoff, Sergio; Matus, Jean Pierre; Ramírez, María Cecilia: Lecciones de Derecho Penal Chileno: Parte Especial, Santiago, Editorial Jurídica de Chile, 2006, p.574.
} 
detención, dicta normas de protección a los derechos del ciudadano y que, entre otros bienes, tutela la libertad ambulatoria de las personas y su limitación sólo en casos expresamente determinados por ley; y finalmente, la ley $\mathrm{N}^{\circ} 19.733$, publicada el 04.06.2001, que regula la libertad de opinión e información, el ejercicio del periodismo y los delitos cometidos a través de un medio de comunicación social, con lo que se otorga protección al pluralismo político en una sociedad democrática, limitado con el ejercicio responsable y ético de la actividad periodística, esto es, con el debido respeto a la intimidad y honra de cada individuo.

También un núcleo importante de normas sujetas a sistematización lo constituyen las leyes penales que regulan el fenómeno de la corrupción y de traición a la fe pública, de lo que son expresión la ley $\mathrm{N}^{\circ} 19.645$, publicada el 11.12.1999, y la ley $\mathrm{N}^{\circ}$ 19.829, del 08.10.2002, que protegen en sí, como bien jurídico común, el recto funcionamiento de la Administración Pública, cuyos funcionarios tienen un deber especial frente a la consecución de sus finalidades en orden a la prosecución del bien común. ${ }^{30}$

Por último, otro orden de materias que se encuentra incorporado en el fenómeno ascendente de criminalización es la regulación del tráfico vial, cuyo objeto jurídico de protección es la seguridad en el tránsito de rodados. Así, es expresión regulatoria de esta situación y tiene como objetivo disminuir los efectos nocivos de los accidentes automovilísticos la ley $\mathrm{N}^{\circ}$ 20.068, publicada el 10.12.2005 que introduce diversas modificaciones a la ley $\mathrm{N}^{\circ} 18.290$, y que muta, además, el artículo 492 del Código Penal.

\section{Causas de la expansión del Derecho Penal según Jesús Silva Sánchez}

Parece de utilidad esbozar aquí el planteamiento central del autor español plasmado en su obra intitulada La expansión del Derecho Penal. Aspectos de la politica criminal en las sociedades post-industriales, quien diagnostica, ex ante a la formulación de su tesitura, como realidad de hecho la tendencia claramente dominante en la legislación de los países europeos de un fenómeno de criminalización que se expresa en la creación de nuevas ilicitudes y un aumento de sanciones para los tipos penales ya existentes. ${ }^{31}$

Un primer factor, que es causa de expansión, lo constituye la aparición de nuevos bienes jurídicos - de nuevos intereses o de nuevas valoraciones de intereses preexistentes- y al aumento del valor experimentado por alguno de los que existían con anterioridad. ${ }^{32}$

\footnotetext{
30 Ibid., p. 488.

${ }^{31}$ Silva Sánchez, Jesús María: La expansión... (nota 1), p. 20.

32 Ibid., p. 25.
} 
Nilo - Normativa sustantivo-penal durante los gobiernos de Aylwin, Frei y Lagos...

Como segunda causal de expansión del Derecho Penal se encuentra la configuración del riesgo de procedencia humana como fenómeno social estructural. Lo anterior, se da por el hecho de que buena parte de las amenazas a que los ciudadanos estamos expuestos provienen precisamente de decisiones que otros conciudadanos adoptan en el manejo de los avances técnicos: riesgos más o menos directos para los ciudadanos (como consumidores, usuarios, beneficiarios de prestaciones públicas, etcétera $)^{33}$, que derivan de las aplicaciones técnicas de los desarrollos en la industria, la biología, la genética, la energía nuclear y las comunicaciones, lo que hace que "tales riesgos resulten de difícil anticipación y que se basen en fallos del conocimiento o manejo de las nuevas capacidades técnicas" ${ }^{\prime 3}$, que llevan por añadidura la problemática de definir cuáles son los riesgos relevantes en una sociedad compleja. ${ }^{35}$

En tercer lugar, como otra causa de la expansión que está presente en una verdadera sociedad postindustrial, es la circunstancia de que ésta constituye una sociedad de "objetiva" inseguridad, pues supone el empleo de medios técnicos, la comercialización de productos y la utilización de sustancias cuyos posibles efectos nocivos no se conozcan de modo seguro, por lo que introducen un importante factor de incertidumbre en la vida social.

Una cuarta causal de la expansión dice relación con uno de los rasgos más característicos de la sociedad postindustrial, cual es la sensación general de inseguridad, esto es, una forma especialmente aguda de vivir el riesgo. ${ }^{36} \mathrm{Un}$ conjunto fundamental de factores de riesgo se relaciona con la mutación del sistema económico, que incide en las formas de inserción de los individuos en las relaciones productivas, como en las posibilidades de derivar de ellas recursos para subvenir a la satisfacción de las necesidades básicas. ${ }^{37}$ Además, las innovaciones tecnológicas que se incorporan a los sistemas productivos generan un desempleo estructural, lo que crea una sensación de inseguridad mayor ante la posibilidad de poder seguir procurando los recursos para satisfacer las necesidades humanas en

\footnotetext{
33 Ibid., p. 27.

34 Díez Ripollés, José: "De la sociedad del riesgo a la seguridad ciudadana: un debate desenfocado", en Bacigalupo, Silvana y Cancio, Manuel (Coords.), Derecho penal y politica transnacional, Barcelona, Atelier, 2005, p. 245.

35 Véase a Beck, Ulrich, La sociedad del riesgo mundial, En busca de la seguridad perdida, (Trad.) Carbó, Rosa, Barcelona, Paidos, 2008, pp. 47-75, en su capítulo II se refiere a la determinación del riesgo, "como constructos y definiciones sociales sobre el trasfondo de las correspondientes relaciones de definición. Adoptan la forma de saber (científico o alternativo), razón por la cual su realidad puede dramatizarse o minimizarse, transformarse o simplemente negarse en virtud de qué normas decidan qué es saber y qué no" (p. 55).

36 Silva Sánchez, Jesús-María: La expansión... (nota 1), p. 32.

37 Brandariz, José: "Nuevos Riesgos, Nuevas Ansiedades y Expectativas Sociales en Materia de Seguridad ante el Delito", en Faraldo, Patricia (Dir.); Puente, Luz y Souto, Eva (Coords.): Derecho Penal de Excepción, Terrorismo e Inmigración, Valencia, Tirant lo Blanch, 2007, p. 142.
} 
el futuro. ${ }^{38}$ Otra fuente de factores de inseguridad es la crisis de referentes identitarios y de socialización básicos sobre los que se sustenta la estructura fundamental de la organización social cuando menos durante buena parte de la Modernidad $^{39}$, como la familia y la mutación de las relaciones de género ${ }^{40} \mathrm{o}$ la crisis de referentes de identificación de base local y territorial. ${ }^{41}$

Como quinta causa de expansión que también se da en una sociedad postindustrial se cuenta la característica de ser una sociedad de sujetos pasivos, en contraposición a la era de la industrialización (siglo XIX y primera parte del XX), en que la colectividad está dispuesta a pagar el precio del desarrollo con la tolerancia de riesgos que se permiten y aceptan. Por contra, en las sociedades postindustriales, hay una reducción de las fronteras del riesgo permitido, pues existe la necesidad de vivir, que limita las fronteras del riesgo permitido ${ }^{42}$, y además, esta composición del concierto social hace que exista una identificación con la víctima del delito antes que con el autor.

\subsection{Contraste entre las causas de expansión del Derecho Penal y la realidad nacional}

En esta parte, nuestro estudio busca determinar si existen en las leyes penales sustantivas analizadas expresiones normativas demostrativas de los fenómenos tenidos como causas de la expansión del Derecho Penal, de forma que podamos constatar las similitudes y diferencias de una realidad y otra. De esta manera, en cuanto a la aparición de nuevos bienes jurídicos -sea como nuevos intereses o nuevas valoraciones de intereses preexistentes- son posibles de ser apreciadas en nuestro país aunque con ciertos matices. Por un lado, es cierto que aparecen nuevos bienes jurídicos tutelados, que tienen un carácter novedoso propiamente tal, como son los cuerpos normativos que combaten el tráfico de drogas y el terrorismo, o aquellos referidos a la corrupción y a la traición de la fe pública; sin embargo, no aparece como tópico relevante una regulación penal de carácter medioambiental, y son escasas las expresiones de dicho ámbito: como la Ley General de Pesca y Acuicultura, publicada el 21.01.1992; la ley $\mathrm{N}^{\circ} 19.342$, que regula derechos de obtentores de nuevas variedades, publicada el 03.11 .1994 y la ley $\mathrm{N}^{\circ}$ 19.473, sobre caza, publicada el 27.09.1996, con la inclusión en esta última del artículo 31, que prohíbe la caza, captura o comercialización habitual de especies en peligro de extinción. De esta forma, la anterior legislación constituye

\footnotetext{
${ }^{38}$ Cfr. Beck, Ulrich: La sociedad del riesgo, Hacia una nueva modernidad, (Trad.) Navarro, Jorge; Jiménez, Daniel y Borrás, María, Barcelona, Paidós, 2006, pp. 148-155, en tratamiento sobre el desempleo masivo y la nueva pobreza.

${ }^{39}$ Brandariz, José: "Nuevos Riesgos..." (nota 37), p. 143.

40 Beck, Ulrich: La sociedad... (nota 38), pp. 165-177, sobre las relaciones entre los sexos, dentro y fuera de la familia.

41 Véase desarrollo en Brandariz, José: “Nuevos Riesgos...” (nota 37), p. 144 -145.

${ }^{42}$ Silva Sánchez, Jesús-María: La expansión... (nota 1), p. 44.
} 
Nilo - Normativa sustantivo-penal durante los gobiernos de Aylwin, Frei y Lagos...

una tenue manifestación de desarrollo en esta materia ${ }^{43}$, la que no alcanza a cubrir cuantitativa ni cualitativamente la regulación que se da en este campo en sociedades postindustriales como la hispana.

Por otro lado, sí se encuentran demostraciones de "nuevas valoraciones de intereses preexistentes", como por ejemplo, en el marco de normas relacionadas con la violencia intrafamiliar y de género, como asimismo, con las temáticas de seguridad pública, además de la regulación de la posesión de armas de fuego, la existencia de "barras bravas" en el fútbol, o los ámbitos de la ascendente criminalidad juvenil.

Finalmente, en torno al aumento del valor experimentado por algunos objetos de protección jurídica, ello se trasunta en una más acabada regulación, con la punición de más conductas consideradas afectatorias o lesivas y, además, por el aumento de las penas, lo que tiene consagración en las normas internas que tipifican delitos en que se protege la libertad, indemnidad u honestidad sexual, o en aquellas ilicitudes de carácter patrimonial, específicamente, los delitos de hurto o robo o, concretamente, con tipos penales que tutelan bienes jurídicos de carácter mixto, como el robo con violencia o intimidación o el robo en lugar habitado.

Por otro lado, sobre la configuración del riesgo de procedencia humana como fenómeno social estructural, que deriva de las aplicaciones técnicas de los desarrollos en la industria, la biología, la genética, la energía nuclear y las comunicaciones, es dable señalar que, si bien en Chile se constató la existencia de normativa que versa sobre tal fenómeno, no significó ello una pléyade normativa, ni una particular criminalidad distintiva del período. En efecto, las regulaciones sobre delitos informáticos o cometidos a través de internet por ejemplo, tuvieron escaso desarrollo como para marcar una tendencia y es demostración aislada de aquello, la ley $\mathrm{N}^{\circ} 19.223$, publicada el 07.06.1993, que tipifica figuras relativas a la informática; lo mismo, en el caso de la ley $\mathrm{N}^{\circ} 20.009$, de 01.04.2005, que limita la responsabilidad de los usuarios de tarjetas de crédito por operaciones realizadas con tarjetas extraviadas; en el ámbito de la biología, la ley $\mathrm{N}^{\circ} 19.451$, publicada el 10.04.1996, que regula el trasplante y donación de órganos; y finalmente, la ley $\mathrm{N}^{\circ}$ 19.970, del 06.10.2004, que crea el sistema de registro de ADN.

En el mismo anterior sentido, pero vinculada a la existencia del progreso técnico y el desarrollo de una criminalidad organizada que opera a nivel internacional, lo que en sí constituye un nuevo riesgo, se encuentra cierta legislación del período que toca el avance de las comunicaciones y que está vinculada al financiamiento del terrorismo y el tráfico de drogas, como también

\footnotetext{
43 Véase propuesta de regulación medioambiental para Chile en Matus, Jean Pierre, del mismo: "Conclusiones y propuesta para un nuevo Derecho Penal Ambiental Chileno", en Matus, Jean Pierre (Ed.), Derecho penal del medioambiente: estudios y propuestas para un nuevo derecho penal ambiental chileno, Santiago, Ed. Jurídica de Chile, 2004, pp. 225-242.
} 
aquella que regula la trata de personas, en la ley $\mathrm{N}^{0} 19.409$, de 07.09 .1995 , y en la ley $\mathrm{N}^{\circ} 19.829$, publicada el 08.10 .2002 , en cuanto al cohecho transnacional.

Otra causa de expansión es la existencia de una sociedad de "objetiva" inseguridad, proceso en el que se puede incluir como regulación de tal fenómeno al tráfico vial [ley $\mathrm{N}^{\circ}$ 20.068, publicada el 10.12.2005]. Sin embargo, la materia que por antonomasia se liga per se a este fenómeno es el Derecho Penal económico, y dentro de él, la relación entre las empresas y consumidores, específicamente con la responsabilidad por el producto defectuoso, todo lo cual carece de expresión normativa relevante en materia penal.

La cuarta causa de expansión del Derecho Penal es la sensación general de inseguridad, que lleva a un cambio de paradigma traducido en que los movimientos sociales clásicos de restricción del Derecho Penal ahora aparecen demandando la ampliación de la protección penal que ponga fin a la angustia de la inseguridad permanente. Son los grupos más desprotegidos y requirentes, a los que se resguarda con normativa al efecto, y de ese reclamo dan cuenta expresiones normativas que combaten la corrupción política, los delitos sexuales con víctima vulnerables [los niños] y la violencia intrafamiliar, todos fenómenos complejos asociados a sectores pasivos o dependientes, sectores en crecimiento en nuestro país.

También al eliminarse los espacios de riesgo permitido e incrementarse la apreciación de infracciones de deberes de cuidado, se ha tendido a que nuestra legislación nacional incremente las figuras de peligro y existan numerosas expresiones normativas de adelantamiento punitivo, como queda claro en nuestra fenomenología supra 1. Así, resulta palmario lo anterior, en áreas específicas como en la regulación del combate a la criminalidad organizada [tráfico de drogas y terrorismo], e incluso, a nuestro pesar, en el caso de delitos comunes de frecuente ocurrencia, como en robos y hurtos. Sin embargo, no es posible afirmar lo mismo en el caso de una proliferación marcada de delitos de comisión por omisión, los que, más allá de una casuística puntual, no se encuentran presentes como característica que distinga a la agrupación de criminalización.

A modo de corolario, del contraste realizado, es posible afirmar que falta una simetría entre la realidad nacional con la situación española. Lo anterior, es factible de comprobar si se pondera, por un lado, la escasa regulación medioambiental en sede penal, y por otra, la inexistente legislación regulatoria de los derechos de los consumidores que proteja con normativa penal sustantivo al efecto la criminalidad de las empresas, sea por el producto defectuoso o que persiga a la unidad productiva por su eventual responsabilidad por el daño ambiental que sea consecuencia del proceso productivo.

Es debido a lo anterior que en tal estado de situación más bien se piensa que enfrentamos un fenómeno que está desarrollado, mas no consolidado, que cursa un proceso de evolución desde un modelo de riesgo permitido hacia uno de 
Nilo - Normativa sustantivo-penal durante los gobiernos de Aylwin, Frei y Lagos...

limitación de los mismos que, al menos en la etapa analizada, no logra consolidar "un modelo puro" de sociedad postindustrial, en cuanto al fenómeno de "expansión", pero que, sin embargo, parece reconocer la presencia de algunas características del mismo sin la misma intensidad descrita por Silva.

\section{Conclusiones}

En Chile aparecen nuevos bienes jurídicos que se consideran dignos de protección penal cuya expresión normativa se encuentra en las leyes que regulan el tráfico de drogas, los delitos terroristas y el combate contra la corrupción. Por su parte, un fenómeno como la violencia intrafamiliar o la ascendente criminalidad juvenil son demostrativos de una valoración novedosa respecto de intereses que igualmente existían de antaño, y por último, las normas penales relativas a los delitos de índole sexual o afectatorios de la propiedad, representan un signo evidente del aumento en la valorización experimentada por ciertos objetos de resguardo. No obstante lo anterior, se echa en falta una regulación de carácter medioambiental de raigambre penal sustantiva, la cual es distintiva de la expansión desde el prisma de Silva Sánchez.

No tiene presencia relevante en Chile una regulación normativa penal, propia de una sociedad de "objetiva" inseguridad que suponga el empleo de medios técnicos, la comercialización de productos y la utilización de sustancias cuyos posibles efectos nocivos no se conozcan de modo seguro. Es más, existió un sustento marginal en la regulación del período con relación a la presencia de un Derecho Penal económico asentado, esencialmente que protegiera a consumidores. Es más, por el contrario, constituyó una demostración insigne de lo inverso, en cuanto a la despenalización de estas materias, la ley $\mathrm{N}^{\circ} 19.911$, que crea el Tribunal de Defensa de la Libre Competencia (14.09.2003).

Entonces, el período objeto de estudio se corresponde en Chile a un proceso de evolución desde un modelo de riesgo permitido hacia uno de limitación de los mismos que, al menos, no logró consolidar un modelo puro de sociedad postindustrial en ese punto, lo que hace que se reconozca la presencia de ciertos fenómenos denominados como "causa de la expansión", pero que no sirve para catalogar a nuestro Derecho Penal inmerso en un proceso de "expansión" propiamente tal, sino sólo en una etapa de "intensificación". Lo anterior se fundamenta en que quedan ámbitos relevantes como el Derecho Penal económico con una tenue regulación. 


\section{Cuadro anexo al artículo}

\section{Anexo $\mathrm{N}^{\circ} 1$}

Ley $\mathrm{N}^{\circ}$ 18.978, publicada el 14.05.1990, concede indulto general de rebaja de dos años en condenas impuestas a personas que no tengan la calidad de reincidentes, por sentencia ejecutoriada y cumpliendo sus sanciones, con la excepción de delitos comunes mayores designados en artículo $2^{\circ}$ de la ley/Ley $\mathrm{N}^{\circ}$ 19.488, publicada el 31.12.1996, en cuanto concede amnistía respecto de los delitos previstos en los artículos 353 y 354 del Código Penal, esto es, la ilicitud de suposición de parto y usurpación de estado civil, siempre que la criatura a que se refiera el delito haya sido engendrada por un descendiente o colateral de sus autores y como consecuencia del delito haya quedado inscrito como hijo de ésta/Ley $\mathrm{N}^{\circ} 19.736$ publicada el 19.07.2001, sobre indulto general, con motivo del Jubileo 2000, artículo $1^{\circ}$, letras b) y c) acotado a penas de duración igual o inferior a cinco años [dos meses por cada año o fracción igual o superior a seis meses], y además, rebaja adicional mayores de 70 años y madres. Se excluyen los delitos que tienen como víctima menores de edad y respecto de los cuales se produjere la muerte, lesiones graves y de carácter gravísimo/Ley $\mathrm{N}^{\circ}$ 19.965, publicada el 25.08.2004, que concede beneficios a condenados, circunscrito en su artículo $1^{\circ}$ a las personas que hayan sido condenadas por el delito de asociación ilícita terrorista, contemplado en el artículo $2^{\circ}$, numeral 5 , de la Ley $\mathrm{N}^{\mathrm{o}} 18.314$ o por las conductas descritas en el artículo $8^{\circ}$ del Decreto $\mathrm{N}^{\circ} 400$, de 1978 , que fija el texto refundido, coordinado y sistematizado de la ley $\mathrm{N}^{\circ} 17.798$, sobre control de armas, o en el Decreto $\mathrm{N}^{\circ} 890$, de 1975, que fija el texto actualizado de la ley $\mathrm{N}^{\mathrm{o}} 12.927$, sobre seguridad del Estado, y que también hayan sido condenadas por delitos sancionados en el Código Penal, en el Código de Justicia Militar o en otras disposiciones de las citadas leyes $\mathrm{N}^{\circ}$ s. 17.798 y 12.927 , cumplirán como condena diez años de presidio por la totalidad de los delitos cometidos, salvo los sancionados por la ley $\mathrm{N}^{\mathrm{o}} 18.314$, siempre que los hechos punibles hayan ocurrido entre el 1 de enero de 1989 y el 1 de enero de 1998, procediendo a su respecto un indulto general en cuanto al saldo de las penas de privación de libertad a que hubieran sido condenadas y que excedieran dicho lapso.

\section{Anexo $N^{\circ} 2$}

Ley $\mathrm{N}^{\circ}$ 19.172, publicada el 04.11.1992, sobre arrepentimiento eficaz. En su artículo $4^{\circ}$ hace procedente el beneficio de libertad vigilada para aquellos que abandonen la organización terrorista y confiesen todos los delitos en que hayan participado, proporcione los indicios y pruebas suficientes para el establecimiento de los hechos delictivos y la determinación de responsabilidad de los demás culpables. Posee una vigencia temporal finita, expresado en su artículo $6^{\circ}$, en que se explicita que las disposiciones aplicables al arrepentido, lo son desde la publicación en el Diario Oficial y por el lapso de cuatro años/Ley $\mathrm{N}^{0}$ 19.856, publicada el 04.02.2003, que crea un sistema de reinserción social de los condenados sobre la base de la observación de buena conducta, y en su artículo $1^{\circ}$, previene que la persona que durante el cumplimiento efectivo de una condena privativa de libertad hubiere demostrado un comportamiento sobresaliente tendrá derecho a una reducción del tiempo de su condena equivalente a dos meses por cada año de cumplimiento/Ley $\mathrm{N}^{\circ} 19.962$, publicada el 25.08.2004, dispone la eliminación de ciertas anotaciones prontuariales, y en su artículo $1^{\circ}$ indica que las anotaciones que consten en el Registro General de Condenas establecido en el Decreto Ley $\mathrm{N}^{\circ}$ 645, de 1925, referidas a condenas impuestas por tribunales militares u ordinarios, por hechos acaecidos entre el 11 de septiembre de 1973 y el 10 de marzo de 1990, y sancionados en las leyes $\mathrm{N}^{\mathrm{0}} 12.927$, sobre seguridad del Estado, $\mathrm{N}^{\mathrm{0}} 17.798$, sobre control 
Nilo - Normativa sustantivo-penal durante los gobiernos de Aylwin, Frei y Lagos...

de armas, y $\mathrm{N}^{\mathrm{o}} 18.314$, que determina conductas terroristas y fija su penalidad, o en los Decretos Leyes $\mathrm{N}^{\mathrm{o}}$ s. 77, de 1973 o No 3.627, de 1981, “...serán eliminadas a partir de la fecha de publicación de la presente ley, si se hubiere cumplido la condena o se hubiere extinguido la responsabilidad penal por cualquier otro motivo"/Ley $\mathrm{N}^{\circ} 20.042$, publicada el 23.07.2005, que modifica el Decreto Ley $\mathrm{N}^{\circ} 321$, de 1925, sobre libertad condicional, posibilita acceder a este beneficio a aquellos condenados a presidio perpetuo, por ley $\mathrm{N}^{\circ}$ 18.314, sobre conductas terroristas y en virtud de otros cuerpos legales, una vez cumplidos diez años de pena, y además, que los hechos punibles hayan ocurrido entre el 1 de enero de 1989 y el 1 de enero de 1998, y que los condenados suscriban un compromiso de renuncia inequívoca al uso de violencia.

\section{Anexo $\mathbf{N}^{\circ} 3$}

Ley $\mathrm{N}^{\circ}$ 19.027, publicada el 24.01.1991, que modifica la Ley $\mathrm{N}^{\circ} 18.314$, que determina conductas terroristas y fija su penalidad. Mutación de la descripción típica que contenía el artículo $1^{\circ}$ de la Ley 18.314, que detallaba una enunciación de conductas terroristas a diferencia del presente texto que cambia la sistemática con un nuevo artículo $2^{\circ}$, que enuncia un listado de delitos que pueden calificarse como terroristas sólo en la medida que cumplan con las circunstancias del nuevo artículo $1^{\circ}$ "...que se cometan con la finalidad de producir en la población o en una parte de ella el temor justificado de ser víctima de esos delitos, sea por la naturaleza de los medios empleados, sea por la evidencia de responder a un plan destinado a atentar contra una categoría o grupo de personas." /Ley $\mathrm{N}^{\circ}$ 19.048, publicada el día 13.02.1991, texto que modifica leyes Nos. $18.015,18.150,18.662,18.313$ y 16.643 sobre abusos de publicidad, y específicamente en cuanto a esta última, muta su artículo 21 en cuanto a delitos de injuria o calumnia cometidos por medios de difusión masiva, con la inclusión de hipótesis de hecho que no constituyen injurias que se determinan y conforman apreciaciones que se formulan en artículos de crítica, política, literaria, histórica, artística, científica, técnica y deportiva, "salvo que se manifestare el propósito de injuriar"/Ley $\mathrm{N}^{\circ} 19.221$ publicada 01.06.1993, establece mayoría de edad a los 18 años y modifica cuerpos legales que indica en cuanto sustituye los artículos 359, 363 y 366 del Código Penal y muta la palabra "veinte" por "dieciocho", luego rebaja el umbral de autodeterminación sexual/Ley $\mathrm{N}^{\circ}$ 20.000, publicada el 16.02.2005, que regula el tráfico de drogas, en su artículo $4^{\circ}$, contempla una figura privilegiada, que da cuenta de una actividad de comercio ilícito en pequeñas cantidades/Ley $\mathrm{N}^{\circ}$ 20.014, publicada el 13.05.2005, que introduce modificaciones en la ley $\mathrm{N}^{\mathrm{o}} 17.798$, sobre control de armas, que muta el artículo $9^{\circ}$ del compendio especial, con la inclusión de un nuevo inciso segundo, que morigera la sanción en aquellos casos en que la posesión o tenencia de armas o elementos designados en el artículo 8 de la misma preceptiva, estuviere destinada a fines distintos que los de alterar el orden público, atacar a las Fuerzas Armadas, o a las de orden y seguridad pública como asimismo, el perpetrar otros delitos. En el mismo anterior sentido, se incluye modificación al inciso tercero del artículo $10 \mathrm{y}$ al inciso segundo del artículo 11.

\section{Anexo $\mathrm{N}^{\circ} 4$}

Ley $\mathrm{N}^{\circ} 19.313$ publicada el 21.07.199, en que deroga disposiciones que indica de la ley $\mathrm{N}^{\circ}$ 11.625 sobre estados antisociales y medidas de seguridad/Ley $\mathrm{N}^{\circ} 19.335$, publicada el día 23.09.1994, que establece el régimen de participación en los gananciales, y modifica el Código Civil, la Ley de Matrimonio Civil, el Código Penal, el Código de Procedimiento Penal y otros cuerpos legales que indica, y específicamente en lo concerniente al texto sustantivo penal, deroga los artículos 375 al 381 del Código Penal. Normas relativas a la sanción del adulterio/Ley $\mathrm{N}^{\circ}$ 19.567, publicada el 01.07.1998, que modifica el Código de 
Procedimiento Penal y el Código Penal en lo relativo a la detención, y dicta normas de protección a los derechos del ciudadano. Deroga los delitos asociados a los denominados estados antisociales de vagancia y mendicidad/Ley $\mathrm{N}^{\circ}$ 19.617, publicada el 12.07.1999, que modifica el Código Penal, el Código de Procedimiento Penal y otros cuerpos legales en materias relativas al delito de violación, deroga las normas atingentes al delito de rapto/Ley $\mathrm{N}^{\circ}$ 19.911, publicada el 14.11.2003, que crea el Tribunal de Defensa de la Libre Competencia, en cuanto deroga ilicitudes asociadas a conductas atentatorias a la libre competencia dentro del país, ejecutadas en el desarrollo de actividades económicas, que se incorporaban en el artículo $1^{\circ}$ y $2^{\circ}$ del Decreto Ley $\mathrm{N}^{\circ} 211$, de 1973 , según texto refundido, coordinado y sistematizado en Decreto $\mathrm{N}^{\circ}$ 511, de 1980, del Ministerio de Economía, Fomento y Reconstrucción/Ley $\mathrm{N}^{\circ}$ 19.918, publicada el 18.12.2003, en cuanto deroga el número 32 del artículo 496 del Código Penal, que sanciona "...al que con objeto de lucro interpretare sueños, hiciere pronósticos o adivinaciones"/Ley $\mathrm{N}^{\circ}$ 19.947, publicada el 17.05.2004, que establece la nueva ley de matrimonio civil, y deroga desde los artículos 385 al 387, del Código Penal.

\section{Anexo $\mathbf{N}^{\circ} 5$}

Ley $\mathrm{N}^{\circ}$ 19.029, publicada el 23.01.1991, que modifica Código de Justicia Militar, el Código Penal, la ley $\mathrm{N}^{\circ} 12.927$ y la ley $\mathrm{N}^{\circ} 17.798$, en cuanto adecua la derogación de la pena de muerte con algunas disposiciones y en algunos textos legales/Ley $\mathrm{N}^{\circ} 19.734$, publicada el 05.06.2001 y que deroga la pena de muerte. Si bien se incorpora dentro del grupo denominado de "descriminalización", al suprimir la pena de muerte y mutarla por la sanción de presidio perpetuo calificado, el artículo 32 bis, es demostrativo del endurecimiento penal, al elevar el estándar de exigencia para optar a beneficios intrapenitenciarios y la imposibilidad de concesión de amnistía e indultos generales, salvo regulación expresa/Ley $\mathrm{N}^{\circ}$ 19.804, publicada el 24.05.2002, en cuanto deroga pena de muerte en textos legales no adecuados con anterioridad.

\section{Anexo $\mathrm{N}^{\circ} 6$}

Ley $\mathrm{N}^{\circ}$ 19.733, publicada el 04.06.2001, sobre libertad de opinión e información y ejercicio del periodismo, en el inciso final del artículo 29, contempla una causal de atipicidad, al explicitar que "No constituyen injurias las apreciaciones personales que se formulen en comentarios especializados de crítica política, literaria, histórica, artística, científica, técnica y deportiva, salvo que su tenor pusiere de manifiesto el propósito de injuriar, además del de criticar".

\section{Anexo $\mathbf{N}^{\circ} 7$}

Ley $\mathrm{N}^{\circ}$ 19. 366, publicada el día 30 de enero de 1995, que sanciona el tráfico ilícito de estupefacientes y sustancias sicotrópicas, en su artículo $2^{\circ}$, establece una pena menos gravosa para aquel que siembre, plante, cultive o coseche especies vegetales del género Cannabis u otras substancias/Ley $\mathrm{N}^{\circ} 19.450$, publicada el 18.03.1996, en cuanto sustituye escalas de multas que señala y modifica el Código Penal, el Código de Procedimiento Penal, la Ley $\mathrm{N}^{\circ} 18.287$ y el Decreto Ley $\mathrm{N}^{\circ}$ 645, de 1925. Establece una modificación de escalas de las multas de sueldos vitales a unidades tributarias mensuales, lo que lleva consecuencialmente aparejado una mutación de la estructuración de los tipos penales de peculado [artículo 233 del Código Penal], de hurto [artículo 446 del Código Penal], de estafa por fraude en la entrega [artículo 467 del Código Penal] y del delito de incendio [artículo 477 del Código Penal], y que por característica común eleva el umbral de lo sustraído, perjudicado o daño producido para efecto de constituir un simple delito y por ende, amplía el espectro de las faltas para esas respectivas ilicitudes [Se reemplaza el 
Nilo - Normativa sustantivo-penal durante los gobiernos de Aylwin, Frei y Lagos...

número 19 del artículo 494 del Código Penal y califica como falta cuando los montos malversados, defraudados o sustraídos no exceden las cinco unidades tributarias mensuales]. Otra muestra de un "ablandamiento penal" es que en el artículo 494 suprime como sanción los tramos de prisión en sus grados medio a máximo; lo mismo en el artículo 495 con una pena de multa de una a dos unidades tributarias mensuales y en el artículo 496 cuando elimina las voces "prisión en su grado mínimo conmutable en", todas claras muestras de una descriminalización, en su vertiente de rebaja de sanción/Ley $\mathrm{N}^{\circ}$ 19.645, publicada el 11.12.1999, que modifica disposiciones del Código Penal que sancionan delitos de corrupción, contempla atenuación de sanción por vínculo de parentesco en su artículo 250 bis/Ley $\mathrm{N}^{\circ}$ 19.665, publicada el 09.03.2000, que reforma el Código Orgánico de Tribunales e implementa los Tribunales de la Reforma Procesal Penal. Sobre la forma de regulación de la pena en el artículo 164 del Código Orgánico de Tribunales, cuando se dictaren distintas sentencias condenatorias en contra de un mismo imputado, los tribunales que dictaren los fallos posteriores al primero deberán regular la pena "...de modo tal que el conjunto de penas no pueda exceder de aquella que hubiere correspondido de haberse juzgado conjuntamente los delitos"/Ley $\mathrm{N}^{\circ} 20.000$, sobre tráfico de drogas, que sustituye la ley $\mathrm{N}^{\circ} 19.366$, y que en su artículo $1^{\circ}$ inciso segundo, establece una rebaja facultativa en los casos que se trate de drogas o sustancias que no produzcan los efectos graves en contra de la salud previstos para el artículo $1^{\circ}$ del texto legal especial/Ley $\mathrm{N}^{\circ}$ 20.084, publicada el día 07.12.2005, que establece un sistema de responsabilidad de los adolescentes por infracciones a la ley penal, en el artículo 22, fija los límites máximos a las penas privativas de libertad en el caso de jóvenes.

\section{Anexo $\mathrm{N}^{\circ} 8$}

Ley $\mathrm{N}^{\circ}$ 19.738, publicada el 19.06.2001, que establece normas para combatir la evasión tributaria, modifica inciso final del artículo 176 de la Ordenanza de Aduanas, contenida en el DFL N ${ }^{\circ} 2$ del año 1997, que expresa: "En estos delitos, deberán considerarse las siguientes circunstancias atenuantes calificadas siempre que ocurran antes del acto de fiscalización: a) la entrega voluntaria a la Aduana de las mercancías ilegalmente internadas al país; b) el pago voluntario de los derechos e impuestos de las mercancías cuestionadas"/Ley $\mathrm{N}^{\circ}$ 19.806, publicada el 31.05.2002, que introduce normas adecuatorias al sistema legal chileno de la reforma procesal penal. Incorpora la redacción del artículo 11, $\mathrm{N}^{\circ}$ 9, del Código Penal, mutación que se incluye como respuesta a la implementación del nuevo sistema procesal penal pero que lleva implícito un designio político-criminal de mayor laxitud interpretativa para su concesión/Ley $\mathrm{N}^{\circ} 19.806$, publicada el 31.05.2002, que regula normas adecuatorias del sistema legal chileno a la reforma procesal penal, en cuanto modifica el DFL N 1 de 1995, del Ministerio de Justicia, coordinado y sistematizado de la ley $\mathrm{N}^{\circ} 19.366$. que sanciona el tráfico ilícito de estupefacientes y sustancias psicotrópicas, que contempla en el artículo 33, como circunstancia atenuante de responsabilidad la cooperación eficaz que conduzca al esclarecimiento de los hechos investigados/Ley $\mathrm{N}^{\circ} 20.000$, publicada el 16.02.2005, sobre tráfico de drogas, en el artículo 22, contempla la denominada cooperación eficaz/ Ley $\mathrm{N}^{\circ}$ 20.066, publicada el 07.10.2005, normativa que establece la Ley de Violencia Intrafamiliar, que en el artículo $11^{\circ}$ del Código Penal, circunstancia número cuatro, incorpora como causal de atenuación "La de haberse ejecutado el hecho en vindicación próxima de una ofensa grave causada al autor, a su cónyuge, o su conviviente..." (la cursiva es mía)/ Ley $\mathrm{N}^{\circ}$ 20.074, publicada el 14.11.2005, que en su inciso cuarto y quinto del artículo 269 bis del Código Penal, establece la atenuante de retractación, designando incluso los casos en que ella puede ser calificada. 


\begin{abstract}
Anexo $\mathbf{N}^{\circ} 9$
Ley $\mathrm{N}^{\circ}$ 19.047, publicada el 14.02.1991, en cuanto modifica diversos textos legales que indica, a fin de garantizar en mejor forma los derechos de las personas. El artículo 11 de la ley en análisis, modifica el artículo 100 del Código Penal, en cuanto a que, para aplicar la prescripción de la pena o de la acción penal, no se entienden ausentes del territorio nacional los que hubieren estado sujetos a prohibición o impedimento de ingreso al país, por el tiempo que les hubiere afectado el impedimento/Ley $\mathrm{N}^{\circ} 19.733$, publicada el 04.06.2001, sobre libertad de opinión e información y ejercicio del periodismo. El artículo 30 en su inciso final establece como causal de exención de responsabilidad el que se probare de parte del querellado la verdad de la imputación y, además, en el artículo 35 exime de responsabilidad a los medios de comunicación social respecto de las opiniones vertidas por parlamentarios de conformidad al artículo 58 de la Constitución Política y de los alegatos hechos por los abogados en los tribunales de justicia/Ley $\mathrm{N}^{\circ} 20.084$, publicada el día 07.12.2005, que establece un sistema de responsabilidad de los adolescentes por infracciones a la ley penal, en el artículo $5^{\circ}$ fija como plazo de prescripción de la acción penal y de la pena en dos años, con la excepción de crímenes, cuyo plazo de prescripción será de cinco años y de las faltas de seis meses.
\end{abstract}

\title{
Anexo $\mathbf{N}^{\circ} 10$
}

Ley $\mathrm{N}^{\circ}$ 19.047, publicada el 14.02.1991, en cuanto modifica diversos textos legales que indica, establece una causal de exención de responsabilidad penal de carácter legal, en el artículo 10 de esta normativa, ya que las personas que posean armas o elementos prohibidos por la ley $\mathrm{N}^{\circ} 17.798$ podrán hacer entrega de ellos a cualquier autoridad pública, dentro de los noventa días de publicación de la ley, quedando exentas de responsabilidad penal que se derive únicamente de la posesión o tenencia indebida/ Ley $\mathrm{N}^{\circ}$ 19.164, publicada el día 02.09.1992, al introducir modificaciones que indica al Código Penal y Código de Procedimiento Penal y derogar la Ley $\mathrm{N}^{\circ}$ 17.010; se introduce legítima defensa privilegiada, en el apartado agregado al $\mathrm{N}^{\circ} 6$ del artículo 10 del Código Penal. Su inclusión empero es de naturaleza persecutoria penal, con el objetivo de contar con mayores herramientas en el combate al delito/Ley $\mathrm{N}^{\circ}$ 19.172, publicada el 04.11.1992, sobre arrepentimiento eficaz. El artículo $1^{\circ}$ previene una causal de exención de responsabilidad para “....aquel que abandone la asociación ilícita terrorista: a) entregue o revele a la autoridad información, antecedentes o elementos de prueba que sirvan eficazmente para prevenir o impedir la perpetración o la consumación de delitos terroristas; b) ayude eficazmente a desarticular a la asociación ilícita, de la cual era parte o a una fracción importante de ella..."/Ley $\mathrm{N}^{\circ}$ 19.806, publicada el día 31.05.2002, que regula normas adecuatorias del sistema legal chileno a la reforma procesal penal, y específicamente en el Código Penal, en el inciso primero del artículo 428 previene que: "El condenado por calumnia o injuria puede ser relevado de la pena impuesta mediante perdón del acusador..."; además, el cuerpo normativo inicialmente citado modificó el DFL N $N^{\circ} 707$ de 1982, del Ministerio de Justicia, que fija el texto refundido, coordinado y sistematizado de la ley sobre cuentas corrientes bancarias y cheques, y que en su artículo 22 sustituye el inciso octavo por el siguiente; "El pago del cheque, los intereses corrientes y las costas judiciales, si las hubiere, constituirá causal de sobreseimiento definitivo, a menos que de los antecedentes aparezca en forma clara que el imputado ha girado el o los cheques con ánimo de defraudar"/Ley $\mathrm{N}^{\circ}$ 19.925, publicada el 19.01.2004, sobre expendio y consumo de bebidas alcohólicas, en su artículo 42 inciso segundo, luego de tipificar la conducta básica en el inciso primero, permite la venta, el obsequio o el suministro de bebidas alcohólicas a menores cuando éstos concurran a almorzar o a comer, acompañados de sus padres, a los recintos destinados a comedores/Ley $\mathrm{N}^{\circ}$ 
Nilo - Normativa sustantivo-penal durante los gobiernos de Aylwin, Frei y Lagos...

20.000, publicada el 16.02.2005, sobre tráfico de drogas, en el inciso final del artículo 25, determina la exención de responsabilidad penal de los agentes encubiertos, agentes reveladores e informantes, en sus actuaciones como "agente encubierto o agente revelador"/Ley $\mathrm{N}^{\circ}$ 20.014, publicada el día 13.05.2005, que modifica la ley $\mathrm{N}^{\circ} 17.798$, sobre control de armas, con la inclusión del artículo $14 \mathrm{c}$, en cuanto a que constituye una circunstancia eximente de responsabilidad "...la entrega voluntaria de las armas o elementos a las autoridades...”/Ley $\mathrm{N}^{\circ} 20.084$, publicada el día 07.12.2005, que establece un sistema de responsabilidad de los adolescentes por infracciones a la ley penal, en su artículo $4^{\circ}$ contiene una regla especial para los delitos sexuales, en cuanto no puede procederse criminalmente respecto de los delitos de los artículo 362, 365, 366 bis y 366 quáter del Código Penal, “...cuando la conducta se hubiere realizado con una persona menor de 14 años y no concurra ninguna de las circunstancias enumeradas en los artículo 361 o 363 de dicho Código, según sea el caso, a menos que exista entre aquélla y el imputado una diferencia de, a lo menos, dos años de edad, tratándose de la conducta descrita en el artículo 362, o de tres años en los demás casos".

\section{Anexo $\mathbf{N}^{\circ} 11$}

Ley $\mathrm{N}^{\circ}$ 19.077, publicada el día 14.08.1991, que introduce modificaciones al Código de Procedimiento Penal en lo relativo a los delitos de robo y hurto, con la inclusión de la figura típica de obstrucción a la justicia/Ley $\mathrm{N}^{\circ}$ 19.088, publicada el día 19.10.1991, que establece normas sobre cotejo de documentos con copias o fotocopias de los mismos, en actuaciones o presentaciones relacionadas con los asuntos que indica/Ley $\mathrm{N}^{\circ} 19.091$, publicada el día 07.11.1991, que modifica el título VII de la Ley $\mathrm{N}^{\circ}$ 18.168, específicamente en su artículo 36/Ley General de Pesca y Acuicultura, Decreto Supremo $\mathrm{N}^{\circ}$ 430, publicada el 21.01.1992, ver su Título X, "Delitos especiales y penalidades"/Ley $\mathrm{N}^{\circ}$ 19.214, publicada el 06.05.1993, en cuanto crea fondo para la capacitación y formación sindical, con una nueva ilicitud en el artículo 11/Ley $\mathrm{N}^{\circ} 19.220$, publicada el 31.05.1993, regula establecimiento de bolsas de productos agropecuarios, artículo 38/Ley $\mathrm{N}^{\circ}$ 19.223, publicada el 07.06.1993, tipifica figuras relativas a la informática, artículos 1,2, 3 y 4/Ley $\mathrm{N}^{\circ}$ 19.227, publicada el 10.07.1993, crea Fondo Nacional de Fomento del Libro y la Lectura, artículos 11 y 12/Ley $\mathrm{N}^{\circ} 19.325$ de violencia intrafamiliar, publicada el día 27.08.1994, que en su artículo 1 inciso primero, predetermina el acto de violencia intrafamiliar, que lleva como bien jurídico tutelado, en mi opinión, la "paz familiar"/Ley $\mathrm{N}^{\circ}$ 19.327, publicada el 31.08.1994, que regula la comisión de delitos con ocasión de espectáculos de fútbol profesional. La nueva descripción típica se plasma en el artículo $6^{\circ}$ de esta normativa: "El que con motivo u ocasión de un espectáculo de fútbol profesional, causare lesiones a las personas o daños a bienes en el recinto en que tiene lugar o en sus inmediaciones, antes, durante o después de su desarrollo". Además, en el inciso final del artículo $6^{\circ}$ de esta ley, se tipifica una figura culposa, cuyos sujetos activos son los representantes de clubes, por su actuar negligente o con descuido culpable en el ejercicio de sus funciones conforme a las obligaciones que les impone la ley/Ley $\mathrm{N}^{\circ} 19.342$, regula derechos de obtentores de nuevas variedades vegetales, Título VI, "De los delitos y sanciones", en su artículo 44/Ley 19.353, publicada el 21.11.1994, condona deudas que indica respecto de predios derivados del proceso de Reforma Agraria, artículo $3^{\circ}$ inciso final/Ley 19.366, publicada el día 30.01.1995, que sanciona el tráfico ilícito de estupefacientes y sustancias sicotrópicas, en su artículo 22 tipifica la asociación ilícita para la comisión de alguno de los tipos penales de la ley de drogas./Ley $\mathrm{N}^{\circ} 19.409$, publicada el 07.09.1995, que agrega el artículo 367 bis al Código Penal y tipifica la trata de personas/Ley $\mathrm{N}^{\circ}$ 19.423, publicada el 20.11.1995, normativa en que se agregan las disposiciones que indica en el Código Penal, en lo relativo a delitos contra el respeto y 
protección a la vida privada y pública de la persona y su familia, en los nuevos artículos $161 \mathrm{~A}$ y $161 \mathrm{~B}$ del texto sustantivo penal/Ley $\mathrm{N}^{\circ}$ 19.451, publicada el 10.04.1996, que establece normas sobre trasplante y donación de órganos, incorpora un tipo penal en su artículo 13/Ley $\mathrm{N}^{\circ} 19.465$ publicada el 02.08.1996, que establece sistema de salud de las Fuerzas Armadas, con un nuevo tipo penal en el artículo 39/Ley $\mathrm{N}^{\circ} 19.473$, publicada el 27/09/1996, que sustituye texto de la Ley $\mathrm{N}^{\circ} 4.601$, sobre Caza, se incorpora en el artículo 30, una serie de conductas infractoras, verbigracia, la prohibición de caza de fauna silvestre o la caza o captura, encontrándose suspendido la autorización o permiso correspondiente, y también se contempla como nuevo tipo penal el artículo 31, que sanciona con pena de presidio menor en su grado mínimo a medio, multa de cinco a cien unidades tributarias mensuales y con el comiso de las armas o instrumentos de caza o de captura, a quienes cazaren, capturaren o comerciaren habitualmente especies de la fauna silvestre cuya caza o captura esté prohibida o de las señaladas en el artículo 22 [animales pertenecientes a especies en peligro de extinción, vulnerables, raras o escasamente conocidas y protegidas]/Ley $\mathrm{N}^{\circ} 19.518$, publicada el 14.10.1997, fija nuevo estatuto de capacitación y empleo, véase en su artículo 81/Ley N ${ }^{\circ} 19.532$ publicada el 17.11.1997, que crea el régimen de jornada escolar completa diurna y dicta normas para su aplicación, posee un nuevo tipo penal en el inciso penúltimo del artículo 8/Ley $\mathrm{N}^{\circ} 19.567$, publicada el 01.07.1998, que modifica el Código de Procedimiento Penal y el Código Penal en lo relativo a la detención, y dicta normas de protección a los derechos del ciudadano, específicamente el artículo 150 de esta normativa, destinado para el que ".....decrete o prolongue indebidamente la incomunicación de una persona privada de libertad..."y al "...que arbitrariamente hiciera arrestar o detener en otros lugares que los establecidos por la ley". Supone que debe tratarse de un empleado público, si se interpreta sistemáticamente con el nuevo artículo 150 b), cuyo sujeto activo son a contrario sensu, los particulares/Ley $\mathrm{N}^{\circ}$ 19.617, publicada el 12.07.1999, que modifica el Código Penal, el Código de Procedimiento Penal y otros cuerpos legales en materias relativas al delito de violación. Inclusión del delito de sodomía, el que se mantiene incólume a la fecha en la descripción penal y sanciones; además, del tipo penal del artículo 366 de abuso sexual propio, con diversas penas a las actuales y del artículo 366 bis Código Penal, del abuso sexual impropio y la ilicitud de la exposición del menor a actos de significación sexual en el artículo 366 quáter del cuerpo legal antes citado/Ley $\mathrm{N}^{\circ} 19.620$, publicada el 05.08.1999, que dicta normas sobre adopción de menores. Referencia a su artículo 39, que debe cometerlo "un funcionario público", además del artículo 40, 41 y 42 de la referida preceptiva/ Ley $\mathrm{N}^{\circ}$ 19.644, publicada el 27.11.1999, en cuanto crea fondo para la modernización de las relaciones laborales y desarrollo sindical, artículo 15/Ley $\mathrm{N}^{\circ} 19.645$, publicada el 11.12.1999, que modifica disposiciones del Código Penal que sancionan delitos de corrupción. Incorporación artículo 240 bis Código Penal, de negociaciones incompatibles a través del ejercicio de influencias; artículo 241 del mismo cuerpo normativo, de exacciones ilegales o consunción; artículo 247 bis del Código Penal, de uso de información privilegiada; artículo 248 bis del Código Penal, la ilicitud de cohecho pasivo propio agravado; artículo 249 Código Penal, de cohecho pasivo impropio y el artículo 250 del Código Penal de cohecho activo o soborno/Ley No 19.669, publicada el 05.05.2000, establece nuevas medidas de desarrollo para las provincias de Arica y Parinacota, en cuanto introduce modificaciones en la ley $\mathrm{N}^{\circ} 19.420$, y agrega un nuevo artículo 35, que en su inciso décimo describe una nueva ilicitud/ Ley $\mathrm{N}^{\circ}$ 19.687, publicada el 06.07.2000, que establece obligación de secreto para quienes remitan información conducente a la ubicación de detenidos desaparecidos. En el inciso tercero del artículo único de esta normativa, con fines político-criminales específicos, crea un tipo penal, que sanciona la comunicación, divulgación o revelación del nombre o datos de 
Nilo - Normativa sustantivo-penal durante los gobiernos de Aylwin, Frei y Lagos...

quienes hayan proporcionado la información a que se hace referencia en el inciso primero [ubicación de los denominados “detenidos desaparecidos"]/Ley $\mathrm{N}^{\circ} 19.694$, publicada el 22.09.2000, que modifica el artículo 73 del Código de Minería. En su artículo único, modifica el artículo 73 del Código de Minería y sustituye su inciso segundo, por el siguiente: "El ingeniero o perito que a sabiendas infringiere la prohibición del inciso precedente sufrirá la pena de reclusión menor en su grado mínimo, y la accesoria de suspensión de cargo u oficio público o profesión titular"/Ley $\mathrm{N}^{\circ} 19.728$, publicada el 14.05.2001, que establece un seguro de desempleo, nuevo tipo penal en el artículo 45/Ley $\mathrm{N}^{\circ}$ 19.738, publicada el 19.06.2001, en cuanto introduce modificaciones en el Código Tributario, e incorpora nuevos tipos penales, con un nuevo inciso final del artículo 97 del Código Tributario, al igual que un nuevo numeral 22 y el inciso primero del número 23 del precitado artículo. Además, con esta normativa se incorpora un nuevo inciso segundo y tercero del artículo 168 de la Ordenanza de Aduanas, contenida en el DFL $N^{\circ} 2$ del año 1997, del Ministerio de Hacienda, y se regula la ilicitud de contrabando y además, un nuevo artículo 168 bis, que tipifica la declaración maliciosamente falsa del peso, cantidad o contenido de las mercancías de exportación/Ley $\mathrm{N}^{\circ}$ 19.764, publicada el 19.10.2001, que regula el reintegro parcial de los peajes pagados en vías concesionadas por vehículos pesados, con su artículo $3^{\circ}$, se remite eso sí, a la sanción contemplada en el inciso segundo del $\mathrm{N}^{\circ} 4$ del artículo 97 del Código Tributario/Ley $\mathrm{N}^{\circ}$ 19.806, publicada el 31.05.2002, que regula las normas adecuatorias del sistema legal de la reforma procesal penal, con un nuevo tipo penal en el artículo 269 del Código Penal, delito de carácter funcionario; en cuanto al DFL $\mathrm{N}^{\circ} 1$ de 1995, del Ministerio de Justicia, coordinado y sistematizado de la Ley $\mathrm{N}^{\circ}$ 19.366, que sanciona el tráfico ilícito de estupefacientes y sustancias psicotrópicas, establece un nuevo tipo penal que sanciona la prohibición de divulgación en el artículo 33 b) inciso segundo, de la preceptiva antes citada; y finalmente, se introducen modificaciones en la ley $\mathrm{N}^{\circ} 18.314$, normativa que determina conductas terroristas y fija su penalidad, y se crean sendos tipos penales en sus artículos 16 y 20/Ley $\mathrm{N}^{\circ}$ 19.829, publicada el 08.10.2002, en cuanto modifica el Código Penal respecto del delito de cohecho, en el nuevo artículo 250 bis a, el denominado "cohecho transnacional"/Ley $\mathrm{N}^{\circ}$ 19.830, publicada el 04.10.2002, en cuanto modifica el Código penal para proteger la seguridad de los voluntarios de los cuerpos de bomberos en actos de servicio, en el nuevo artículo 268 bis/Ley $\mathrm{N}^{\circ}$ 19.846, publicada el 04.01.2003, sobre calificación de la producción cinematográfica, en el inciso segundo del artículo 30, crea un tipo penal/Ley $\mathrm{N}^{\circ}$ 19.882, publicada el 23.06.2003, regula nueva política de personal a los funcionarios públicos que indica, en su artículo vigésimo tercero/Ley $\mathrm{N}^{\circ}$ 19.885, publicada el 06.08.2003, que incentiva y norma el buen uso de donaciones que dan origen a beneficios tributarios y los extiende a otros fines sociales y públicos, en cuanto agrega un nuevo numeral 24 al artículo 97 del Código Tributario/Ley $\mathrm{N}^{\circ} 19.906$, publicada el 13.11.2003, que modifica la Ley $\mathrm{N}^{\circ} 18.314$ sobre conductas terroristas, en orden a sancionar más eficazmente la financiación del terrorismo, e incorpora un nuevo artículo 8, en la normativa última, anteriormente citada/Ley $\mathrm{N}^{\circ} 19.913$, publicada el 18.12.2003, en cuanto crea la Unidad de Análisis Financiero, con nuevas ilicitudes en los artículos 6, 13 inciso primero y 19 en sus letras a) y b), $20 \mathrm{~N}^{\circ} \mathrm{s} 1$ y 2 , todos de la normativa anteriormente citada/Ley $\mathrm{N}^{\circ}$ 19.914, publicada el 19.11.2003, en cuanto adecua la legislación que indica al Tratado de Libre Comercio con los Estados Unidos de América, y modifica la Ley $\mathrm{N}^{\circ} 17.336$ e incluye una nueva ilicitud en el artículo 81 ter de la última normativa antes citada/Ley $\mathrm{N}^{\circ}$ 19.925, publicada el 19.01.2004, sobre expendio y consumo de bebidas alcohólicas, tipifica conducta en el inciso primero del artículo 42/Ley $N^{\circ}$ 19.927, publicada el 14.01.2004, en cuanto modifica el Código Penal en materia de delitos de pornografía infantil e incorpora nuevo tipo penal en el artículo 365 
bis sobre introducción de objetos o utilización de animales, al igual un nuevo 374 bis/Ley $\mathrm{N}^{\circ}$ 19.932, publicada el 03.02.2004, que modifica la ley general de urbanismo y construcciones, en materia de contrato de promesa de compraventa de determinados bienes raíces y criminaliza conducta constitutiva de estafa en el artículo 470 del Código Penal; en efecto, se incorpora un nuevo numeral noveno en esta disposición/Ley $\mathrm{N}^{\circ}$ 19.934, publicada el 21.02.2004, que modifica el D.L. $\mathrm{N}^{\circ} 3.500$, de 1980, estableciendo normas relativas al otorgamiento de pensiones a través de la modalidad de rentas vitalicias, en cuanto modifica el D.L. 3.500, de 1980, tipificando una ilicitud en el inciso penúltimo del artículo 23 del decreto antes citado/Ley $\mathrm{N}^{\circ} 19.968$, publicada el 30.08.2004, que crea los tribunales de familia, y en su artículo 84 establece la obligación de denunciar los hechos que pudieren constituir violencia intrafamiliar para las personas designadas en el artículo 175 del Código Procesal Penal y su incumplimiento lleva aparejada como sanción la pena prevista en el artículo 494 del compendio sustantivo penal/Ley $\mathrm{N}^{\circ}$ 19.970, publicada el 06.10.2004, en cuanto crea el sistema nacional de registros de ADN, incorpora nuevas ilicitudes en los artículos 19 y 20/Ley $\mathrm{N}^{\circ} 19.974$, publicada el 02.10.2004, que regula el sistema de inteligencia del estado y crea la Agencia Nacional de Inteligencia, establece dos tipos penales, uno, en el inciso primero y otro, en el segundo, ambos del artículo 43 de esta normativa. Además, contempla una figura típica novedosa en el artículo 44 de esta ley/Ley $\mathrm{N}^{\circ}$ 19. 975, publicada el 05.10.2004, normativa que modifica el Código Penal en materia de uso y porte de armas, incorpora como nuevo tipo penal el de porte de armas cortantes o punzantes en determinados lugares, que se mencionan en el artículo 288 bis del compendio sustantivo penal/Ley $\mathrm{N}^{\circ} 19.979$, publicada el 06.11.2004, modifica el régimen de jornada escolar completa diurna y otros cuerpos legales, y modifica la ley $\mathrm{N}^{\circ} 19.532$ en su artículo $8^{\circ}$, como literal g) incluye una nueva ilicitud que reza a la letra: "El que proporcionare antecedentes falsos o adulterados con el propósito de obtener el aporte suplementario por costo de capital adicional a que se refiere esta ley, será sancionado con la pena de presidio menor en su grado mínimo"/ Ley $\mathrm{N}^{\circ} 20.000$, publicada el día 16.02.2005, sobre tráfico de drogas, en el inciso primero del artículo 12 y 13 , y 29, se incluyen nuevas ilicitudes/Ley $\mathrm{N}^{\circ} 20.009$, que limita la responsabilidad de los usuarios de tarjetas de crédito por operaciones realizadas con tarjetas extraviadas, hurtadas o robadas; en su artículo $5^{\circ}$, tipifica el delito de uso fraudulento de tarjeta de crédito o débito/Ley $\mathrm{N}^{\circ}$ 20.014, publicada 13.05.2005, que introduce modificaciones en la ley $\mathrm{N}^{\circ} 17.798$, sobre control de armas, incluye un nuevo artículo $9^{\circ}$ a) y 17 a)/ Ley $\mathrm{N}^{\circ}$ 20.048, publicada el 31.08.2005, que introduce modificaciones legales en materia de desacato, e incorpora nuevos tipos penales en el inciso primero y segundo del artículo 264 del Código Penal y en el artículo 276 del Código de Justicia Militar/Ley $\mathrm{N}^{\circ} 20.045$, publicada el 10.09.2005, que moderniza el servicio militar obligatorio, artículo $72,73,73$ a), 73 b) y $75 /$ Ley $\mathrm{N}^{\circ} 20.066$, publicada el 07.10.2005, normativa que establece la ley de violencia intrafamiliar, que en su artículo $10^{\circ}$ inciso primero remite expresamente el incumplimiento de determinadas medidas cautelares de esta normativa especial hacia el tipo penal de desacato, eliminando cualquier eventual discusión acerca de la idoneidad de estas resoluciones judiciales, conforme a la naturaleza de esencialmente revocables que ellas poseen, para configurar la ilicitud antes referida/ Ley $\mathrm{N}^{\circ}$ 20.088, publicada el 05.01.2006, que establece como obligatoria la declaración jurada patrimonial de bienes a las autoridades que ejercen una función pública, incorpora un nuevo artículo 241 bis del Código Penal/Ley $\mathrm{N}^{\circ} 20.090$, publicada el 11.01.2006, que sanciona con mayor vigor el abigeato y facilita su investigación, que tipifica de una manera específica en el artículo 448 bis del Código Penal, el robo o hurto de caballos o bestias de silla o porcino. Incorpora, además un nuevo tipo penal en el artículo 448 quinquies del Código Penal, que sanciona al que se apropie de las plumas, 
Nilo - Normativa sustantivo-penal durante los gobiernos de Aylwin, Frei y Lagos...

pelos, crines, cerdas o cualquier elemento del pelaje de los animales ajenos, por cualquier medio que ello se realice.

\section{Anexo $\mathbf{N}^{\circ} 12$}

Ley $\mathrm{N}^{\circ}$ 19.366, publicada el día 30.01.1995, que sanciona el tráfico ilícito de estupefacientes y sustancias sicotrópicas, en su artículo 12: "El que, a sabiendas que determinados bienes, valores, dineros, utilidad, provecho o beneficio se han obtenido o provienen de la perpetración en Chile o en el extranjero, de hechos constitutivos de alguno de los delitos contemplados en esta ley..."/Ley $\mathrm{N}^{\circ}$ 19.413, publicada el 20.09.1995, en cuanto introduce modificaciones al Código Penal y deroga la antigua descripción típica del delito de receptación en la que se le concebía como forma de encubrimiento por aprovechamiento y como una forma de participación asimilada a la complicidad. Se establece el nuevo artículo 456 bis A del Código Penal/Ley $\mathrm{N}^{\circ}$ 19.491, publicada el 29.01.1997, regula funcionamiento de administradoras de recursos financieros de terceros destinados a la adquisición de bienes en su artículo 8/Ley $\mathrm{N}^{\circ} 19.495$, publicada el 08.03.1997, normativa que modifica la Ley $\mathrm{N}^{\circ} 18.290$, Ley de Tránsito, en lo relativo a la obtención de licencias de conducir. Tiene relevancia para la materia penal, las modificaciones en el título XVII, y su nuevo epígrafe "De los delitos, cuasidelitos y contravenciones", y el subtítulo "De los delitos y cuasidelitos", y existe en el artículo 196 A, un delito que puede sólo ser cometido cuando el sujeto activo sea un "empleado público que abusando de su oficio", "otorgue indebidamente" licencias de conductor, u "otorgue falsamente" certificados que permitan obtener una licencia de conductor, o "comete falsedades de las del artículo 193 del Código Penal" en las inscripciones de vehículos, o finalmente, el que infringe las normas de la Ley 18.290 para el otorgamiento de placa patente. En el mismo sentido, el artículo 196 A bis, en el que, aparte de las conductas antes descritas para un particular, sanciona en su letra d) a quien obtiene licencia de conductor sin cumplir con los requisitos legales, mediante soborno, dádivas, uso de influencias indebidas/Ley $\mathrm{N}^{\circ}$ 19.709, publicada el 31.01.2001, establece régimen de zona franca industrial de insumos, partes y piezas para la minería en la comuna de Tocopilla en la II Región, artículo 10/Ley No 19.927, publicada el 14.01.2004, modifica el Código Penal en materia de delitos de pornografía infantil, y en cuanto a la mutación en la redacción de los artículos 366, 366 bis, 366 quáter, 366 quinquies, 367 y 367 ter, todos del Código Penal, son demostraciones de adecuaciones a la realidad actual unidas a un innegable endurecimiento en las sanciones que se imponen, ello en relación a esas situaciones que ahora se regulan de manera distinta/Ley $\mathrm{N}^{\circ} 19.946$, publicada el 11.05.2004, que modifica la ley austral en materia de crédito tributario y establece la ampliación de la Zona Franca de extensión de Punta Arenas a la Región de Aysén para bienes de capital, en su artículo 2 inciso penúltimo, en cuanto a la ilicitud de contrabando/Ley $\mathrm{N}^{\circ}$ 19.947, publicada el 17.05.2004, que establece nueva ley de matrimonio civil, y reemplaza el artículo 389 del Código Penal, por uno que se adecua a la nueva preceptiva de matrimonio civil/Ley $\mathrm{N}^{\circ}$ 19.950, publicada el 05.06.2004, que aumenta sanciones a hurtos y facilita su denuncia e investigación, que tipifica de forma independiente la falta de hurto en el artículo 494 bis del Código Penal/Ley $\mathrm{N}^{\circ} 20.014$, publicada 13.05.2005, que introduce modificaciones en la ley $\mathrm{N}^{\circ} 17.798$, sobre control de armas, e incluye una serie de presupuestos no contemplados con anterioridad a esta modificación legal, y especialmente la enmienda al artículo $3^{\circ}$, con la inclusión de un nuevo inciso tercero, que prohíbe la posesión o tenencia de armas de fabricación artesanal transformadas respecto de su condición original, sin la autorización de la Dirección de Movilización Nacional/Ley $\mathrm{N}^{\circ}$ 20.014, publicada el día 13.05.2005, que modifica la ley $\mathrm{N}^{\circ} 17.798$, sobre control de armas, que se sitúa en una hipótesis nueva, cual es el porte de 
armas que son de uso bélico o de aquellas establecidas en el inciso final del artículo $3^{\circ}$ de la ley, adminículos novedosos conforme a la evolución de la fábrica armamentista/Ley $\mathrm{N}^{\circ}$ 20.061, publicada el 10.09.2005, que modifica la ley $\mathrm{N}^{\circ} 17.798$, sobre control de armas y explosivos, que sustituye el inciso primero del artículo 18 del compendio especial de leyes anteriormente referido, que conforme a su parte final otorga competencia a los tribunales de garantía y orales en lo penal respecto de las ilicitudes contempladas en los artículos 13 y 14, cuando estos tipos penales "...se cometan con bombas o artefactos incendiarios, con armas de fabricación artesanal o transformadas respecto de su condición original, o bien con armas cuyos números de serie se encuentren adulterados o borrados"/Ley $\mathrm{N}^{\circ}$ 20.064, publicada el día 29.09.2005, que aumenta las penas en los casos de delitos de maltrato de obra a carabineros, en las modificaciones a los artículos 416, 416 bis y 417 del Código de Justicia Militar. Además, las modificaciones introducidas al artículo 17, 17 bis y 17 quáter del Decreto Ley N².460, de 1979, ley orgánica de la Policía de Investigaciones de Chile/ Ley $\mathrm{N}^{\circ}$ 20.066, publicada el 07.10.2005, normativa que establece la ley de violencia intrafamiliar, y en su artículo $5^{\circ}$ define qué se entiende por una acto de violencia intrafamiliar y entre qué personas puede producirse conforme a las ligazones parentales y de afecto en el inciso primero y segundo de la disposición/Ley $\mathrm{N}^{\circ} 20.068$, publicada el 10.12.2005, que introduce diversas modificaciones a la ley $\mathrm{N}^{\circ} 18.290$, en materia de tránsito terrestre, con la modificación del artículo 196 A bis, que pasa a ser artículo $196 \mathrm{~B}$, en sus letra e) y g), de la última normativa antes citada, como asimismo con la incorporación de un nuevo inciso final con nuevas hipótesis de configuración. Lo mismo ocurre con la tipificación del artículo 196 c), que sanciona la conducción o manejo bajo la influencia del alcohol/Ley $\mathrm{N}^{\circ} 20.074$, publicada el 14.11.2005, en cuanto modifica el Código Penal, y sustituye los artículo 206, 207, 208 y 212 del compendio sustantivo penal. En el mismo sentido la redacción actual del artículo 269 bis del Código Penal.

\section{Anexo $\mathbf{N}^{\circ} 13$}

Ley $\mathrm{N}^{\circ}$ 19.039, publicada el 25.01.1991, sobre propiedad industrial, artículos 52, 61 y 67, en sus incisos penúltimos, en donde se establece como sanción el comiso de los utensilios y elementos derechamente empleados en la comisión de las ilicitudes que expresamente se contemplan en las disposiciones citadas/Ley $\mathrm{N}^{\circ} 19.325$ de violencia intrafamiliar, publicada el día 27.08.1994, en su artículo $4^{\circ}$ se especifican las sanciones contenidas para los actos violentos que se den en contexto intrafamiliar, a saber, asistencia obligatoria, multa y prisión/Ley $\mathrm{N}^{\circ}$ 19.327, publicada el 31.08.1994, que regula la comisión de delitos con ocasión de espectáculos de fútbol profesional, y en su artículo $7^{\circ}$ se incorporan como penas accesorias la de inhabilitación para ser dirigente y la prohibición de asistencia a los espectáculos de fútbol mientras dure la condena y la inhabilitación para asociarse a un club profesional o integrar su barra/Ley $\mathrm{N}^{\circ}$ 19. 410, publicada el 02.09.1995, en cuanto introduce modificaciones a la Ley $\mathrm{N}^{\circ} 19.070$ : 1.- Sustitúyese el inciso primero del artículo $4^{\circ}$ por el siguiente: "Sin perjuicio de las inhabilidades señaladas en la Constitución y la ley, no podrán ejercer labores docentes quienes sean condenados por alguno de los delitos contemplados en la ley No. 19.366 y en los párrafos 1, 4, 5, 6 y 8 del Título VII y en los párrafos 1 y 2 del Título VIII del Libro Segundo del Código Penal."/Ley $N^{\circ}$ 19.617, publicada el 12.07.1999, que modifica el Código Penal, el Código de Procedimiento Penal y otros cuerpos legales en materias relativas al delito de violación. En el artículo 370 bis del Código Penal incorpora nuevas sanciones afectatorias a la Patria Potestad/Ley $\mathrm{N}^{\circ}$ 19.927, publicada el 14.01.2004, normativa legal que modifica el Código Penal, el Código de Procedimiento Penal y el Código Procesal Penal en materia de delitos de pornografía infantil, y en relación al compendio sustantivo penal, modifica el artículo 21 y crea la pena de inhabilitación absoluta para cargos, empleos, oficios o profesiones ejercidos en 
Nilo - Normativa sustantivo-penal durante los gobiernos de Aylwin, Frei y Lagos...

ámbitos educacionales o que involucren una relación directa y habitual con personas menores de edad, y en un nuevo artículo 39 bis regula sus efectos/Ley $\mathrm{N}^{\circ}$ 20.000, publicada el día 16.02.2005, sobre tráfico de drogas, impone la clausura del establecimiento en el inciso segundo del artículo 5 de esta normativa/Ley $\mathrm{N}^{\circ} 20.021$, publicada el día 14.06.2005, que modifica la Ley $\mathrm{N}^{\circ} 17.288$, sobre monumentos nacionales, con el nuevo artículo 38 bis, en cuanto a la apropiación de un monumento nacional que sea constitutiva de otras ilicitudes, como la de usurpación, hurto, robo con fuerza en las cosas, robo con violencia o intimidación en las personas y receptación, a la pena privativa de libertad que conllevan añaden una pena de multa de cincuenta a doscientas unidades tributarias mensuales/Ley $\mathrm{N}^{\circ}$ 20.084, publicada el día 07.12.2005, que establece un sistema de responsabilidad de los adolescentes por infracciones a la ley penal, y desde esta perspectiva establece un catálogo de sanciones especiales en el artículo $6^{\circ}$, que a pesar de su eminente finalidad preventivo-especial, constituyen penas distintas a las contempladas en el sistema penal de adultos y por ende resultan novedosas sumándose a las ya existentes. En el mismo sentido, se considera la posibilidad que tiene el juez de fijar sanciones accesorias, según lo dispone esta preceptiva en su artículo $7^{\circ}$, como también las penas mixtas, que se pueden ponderar como sanciones distintas de sus vertientes originales.

\section{Anexo $\mathbf{N}^{\circ} 14$}

Ley $\mathrm{N}^{\circ} 19.456$, publicada el 16.05.1996, que posterga la entrada en vigencia de la ley $\mathrm{N}^{\circ}$ 19.450, normativa ésta última de eminente carácter despenalizador./Ley $\mathrm{N}^{\circ} 19.857$ publicada el 11.02.2003, que autoriza el establecimiento de empresas individuales de responsabilidad limitada, y en su artículo 10 inciso segundo prescribe que: "La pena del delito contemplado en el número $2^{\circ}$ del artículo 471 del Código Penal, se aplicará aumentada en un grado si fuere cometido por el titular de una empresa individual de responsabilidad limitada"/Ley $\mathrm{N}^{\circ}$ 19.913, publicada el 18.12.2003, en cuanto crea la Unidad de Análisis Financiero, en su artículo 15 extiende la punición del consumo personal de drogas, más allá de la ilicitud del artículo 41 de la ley 19.366, pues preceptúa la prohibición del personal de la Unidad de Análisis Financiero, de “...el uso o consumo, en lugares públicos o privados...”, locación esta última a la que se hace referencia en el compendio especial de drogas, pero que añade como requisito para su tipificación el concierto previo para tal propósito/Ley $\mathrm{N}^{\circ} 19.925$, publicada 19.01.2004, sobre expendio y consumo de bebidas alcohólicas, que en su artículo 42 inciso tercero, preceptúa que si el expendio de bebidas alcohólicas a un menor de dieciocho años lo efectuare el administrador o dueño del establecimiento, la pena será prisión en su grado máximo, multa de diez a veinte unidades tributarias mensuales y clausura temporal del establecimiento, por un período no superior a tres meses. Además, en los incisos cuarto y quinto, se endurecen las sanciones aplicables, en un caso, si la conducta base se comete además, con vulneración de la prohibición prevista en el artículo 29 de esta ley y segundo lugar, por reiteración de la comisión del delito de expendio a menores de edad, y en cada situación con penas más gravosas/Ley $\mathrm{N}^{\circ}$ 19.950, publicada el 05.06.2004, que aumenta sanciones a hurtos y facilita su denuncia e investigación, que en el artículo 494 bis del Código Penal, inciso tercero, dispone que: "En los casos que participen en el hurto individuos mayores de dieciocho años y menores de esa edad, se aplicará a los mayores la pena que les habría correspondido sin esa circunstancia, aumentada en un grado, si éstos se hubieren prevalido de los menores en la perpetración de la falta". Además, en este mismo artículo, en su inciso final, se altera el tratamiento general de las faltas que se encuentren en desarrollo de iter criminis imperfectos, regulado en el artículo 9 del texto sustantivo penal/Ley $\mathrm{N}^{\circ}$ 20.021, publicada el día 14.06.2005, que modifica la Ley $\mathrm{N}^{\circ}$ 
17.288, sobre monumentos nacionales, en su nuevo artículo 38 bis/Ley $\mathrm{N}^{\circ}$ 20.066, publicada el 07.10.2005, normativa que establece la Ley de Violencia Intrafamiliar, que agrega una oración final en el $\mathrm{N}^{\circ} 5$ del artículo 494 del Código Penal, que impide al tribunal calificar como leves las lesiones cometidas en contra de las personas mencionadas en el artículo 5 de la ley sobre violencia intrafamiliar.

\section{Anexo $\mathbf{N}^{\circ} 15$}

Ley $\mathrm{N}^{\circ}$ 20.084, publicada el día 07.12.2005, que establece un sistema de responsabilidad de los adolescentes por infracciones a la ley penal, en su artículo $1^{\circ}$ fija el contenido de esta preceptiva extendiendo la responsabilidad penal a los adolescentes y determina en su artículo $3^{\circ}$ los límites de edad de ella, para mayores de catorce y menores de dieciocho años.

\section{Anexo $N^{\circ} 16$}

Ley $\mathrm{N}^{\circ}$ 19.393, publicada el día 22.06.1995, en cuanto introduce modificaciones a la ley $\mathrm{N}^{\circ}$ 19.366, describe una hipótesis de hecho no contemplada en el artículo 21 de la Ley $\mathrm{N}^{\mathrm{o}}$ 19.366 - con la creación de un nuevo inciso segundo- que castiga a "los que omiten denunciar u ocultan, alteran o destruyen cualquier tipo de prueba del mismo o de sus partícipes" cuando tomasen conocimiento de alguno de los hechos que configuran el denominado delito de lavado de dinero/Ley $\mathrm{N}^{\circ}$ 19.501, publicada el 15.05.1997, normativa que introduce modificaciones a la ley No 19.450, al Código de Procedimiento Penal y al Código Penal. Así, conforme a la postergación en la entrada en vigencia de la Ley $\mathrm{N}^{\circ} 19.450$, mandatada por Ley $\mathrm{N}^{\circ}$ 19.456, la primera preceptiva en su texto original jamás entró en vigor, teniendo eso sí validez con las modificaciones incorporadas en esta normativa, aunque la presente es de giro absolutamente inverso a la primera, por caracterizarse en general por un endurecimiento de las penas. A modo de ejemplo, en el artículo 170 del Código Penal, se aumenta la sanción, producto de una mutación en los tipos penales, que considera -ahora- como simple delito lo que antes era una mera falta, si el valor de la moneda supera una unidad tributaria mensual; en el anterior mismo sentido, los artículos 189, 233, 446, 467 y 477 Código Penal. Así, se disminuye el campo de punición a título de falta, limitándose sólo a valores inferiores de una unidad tributaria mensual/ Ley $\mathrm{N}^{\circ}$ 19.617, publicada el 12.07.1999, en cuanto modifica el Código Penal, el Código de Procedimiento Penal y otros cuerpos legales, que extiende en los delitos de prevaricación como sujeto pasivo a hombre y mujer, al mutar en la prevaricación por seducción la voz "mujer" por "persona", en artículo 223 del Código Penal; en el mismo sentido en el artículo 258 del Código Penal/ Ley $N^{\circ}$ 19.806, publicada el 31.05.2002, que regula normas adecuatorias del sistema legal chileno de la reforma procesal penal. En los artículos 171, 179 y 184 del Código Penal, se incorpora una nueva descripción que lleva aparejada una extensión en la punición/Ley $\mathrm{N}^{\circ}$ 19.950, publicada el 05.06.2004, que aumenta sanciones a hurtos y facilita su denuncia e investigación, que modifica la descripción típica del numeral $3^{\circ}$ del artículo 446 del Código Penal, por cuanto será simple delito cuando el valor de la cosa hurtada "...excediere de media unidad tributaria mensual y no pasare de cuatro unidades tributarias mensuales"/Ley $\mathrm{N}^{\circ}$ 20.068, publicada el 10.12.2005, que introduce diversas modificaciones a la ley $\mathrm{N}^{\mathrm{0}} 18.290$, en materia de tránsito terrestre, con la modificación del artículo 492 del Código Penal, específicamente con la redacción de su actual inciso segundo.

\section{Anexo No 17}

Ley $\mathrm{N}^{\circ}$ 19.241, publicada el día 28.08.1993, en cuanto modifica artículos que indica del Código Penal y de la ley $\mathrm{N}^{\circ}$ 18.314. Aumento en la sanción del delito de secuestro, 
Nilo - Normativa sustantivo-penal durante los gobiernos de Aylwin, Frei y Lagos...

artículo 141 del Código Penal, en la forma que se indica: a) Sustitúyese en el inciso primero la frase "presidio o reclusión menores en cualquiera de sus grados" por "presidio o reclusión menor en su grado máximo". Además, sustituye el artículo 142 por el actual del Código Penal, en donde se sigue la descripción y tratamiento particular que tienen los menores de edad, con relación a las figuras agravadas del delito de secuestro con penas más rigorosas/Ley $\mathrm{N}^{\circ}$ 19.449, publicada el 08.03.1996, en cuanto introduce modificaciones al Código Penal en lo relativo a delitos de robo y hurto, en particular deja la sanción corporal del delito de robo en lugar habitado situada en una pena de presidio mayor en su grado mínimo conforme lo expresa el artículo 440 del texto sustantivo penal/Ley $\mathrm{N}^{\circ}$ 19.617, publicada el 12.07.1999, en cuanto modifica el Código Penal, el Código de Procedimiento Penal y otros cuerpos legales en materias relativas al delito de violación. En la violación del nuevo artículo 361 del Código Penal, ver extensión de la pena, que va de "presidio menor en su grado máximo a presidio mayor en su grado medio"/Ley $\mathrm{N}^{\circ}$ 19.657, publicada el 07.01.2000, que regula las concesiones de energía geotérmica, y en su artículo 44 incorpora una suerte de presunción del monto sustraído, que en los casos de sustracción de energía geotérmica a un concesionario, cualquiera sea el valor de éstas, hace aplicable las penas previstas en el artículo $446 \mathrm{~N}^{\circ} 1$ del Código Penal/Ley $\mathrm{N}^{\circ}$ 19.659, publicada el 27.12.1999, que establece sanciones a procedimientos de cobranzas ilegales. Sustituye el $\mathrm{N}^{\circ} 1$ del artículo 296 del Código Penal, y sanciona en su $\mathrm{N}^{\circ} 1$ "Con presidio menor en sus grados medio a máximo, si hubiere hecho la amenaza exigiendo una cantidad o imponiendo ilegítimamente cualquiera otra condición y el culpable hubiere conseguido su propósito"/Ley N 19.733, publicada el 04.06.2001, que regula la libertad de opinión e información y el ejercicio del periodismo así como los delitos cometidos a través de un medio de comunicación social en el artículo 29 de esta preceptiva, establece una forma de agravación de la sanción en el delito de calumnia e injuria, cuando ellos se cometen a través de cualquier medio de comunicación social/Ley $\mathrm{N}^{\circ}$ 19.829, publicada el 08.10.2002, en cuanto modifica el Código Penal respecto del delito de cohecho, y cuya demostración de aumento de rigor punitivo es el nuevo artículo 250/Ley N ${ }^{\circ}$ 19.927, publicada el 14.01.2004, en cuanto modifica el Código Penal, y muta la pena del artículo 361 de "presidio menor en su grado máximo a presidio mayor en su grado medio" por "presidio mayor en su grado mínimo a medio"/Ley $\mathrm{N}^{\circ} 20.014$, publicada el 13.05.2005, que introduce modificaciones en la ley $\mathrm{N}^{\circ} 17.798$, sobre control de armas, que muta la pena establecida en el artículo 9 del compendio especial, de "presidio menor en su grado mínimo" a "presidio menor en su grado medio"/Ley $\mathrm{N}^{\circ}$ 20.061, publicada el 10.09.2005, que modifica la Ley $\mathrm{N}^{\circ} 17.798$, sobre control de armas y explosivos, que sustituye la sanción a la ilicitud del artículo 9 A del compendio especial de leyes antes referido, de "presidio menor en su grado mínimo" a "presidio menor en cualquiera de sus grados"/Ley $\mathrm{N}^{\circ}$ 20.090, publicada el 11.01.2006, que sanciona con mayor vigor el abigeato y facilita su investigación, que en el artículo 448 ter del Código Penal, determina un aumento en la sanción de los delitos de robo y hurto en un grado, que es perentorio para el juez, en los casos de sustracción de animales.

\section{Anexo $\mathbf{N}^{\circ} 18$}

Ley $\mathrm{N}^{\circ}$ 19.449, publicada el 08.03.1996, en cuanto introduce modificaciones al Código Penal en lo relativo a delitos de robo y hurto, y a través del artículo 450 bis hace improcedente la atenuante del artículo $11 \mathrm{~N}^{\circ} 7$ del Código Penal en los delitos de robo con violencia o intimidación en las personas/Ley $\mathrm{N}^{\circ}$ 20.000, publicada el 16.02.2005, sobre tráfico de drogas, en el artículo 20, determina la improcedencia de la morigerante del artículo $11 \mathrm{~N}^{\circ} 7$ del Código Penal. 


\begin{abstract}
Anexo $\mathbf{N}^{\circ} 19$
Ley $\mathrm{N}^{\circ}$ 19.366, publicada el día 30.01.1995, que sanciona el tráfico ilícito de estupefacientes y sustancias sicotrópicas, en su artículo 23 contempla seis hipótesis que llevan como consecuencia la elevación del marco penal en un grado/Ley $\mathrm{N}^{\circ} 19.617$, publicada el 12.07.1999, en cuanto modifica el Código Penal, el Código de Procedimiento Penal y otros cuerpos legales en materias relativas al delito de violación, en la nueva descripción típica del artículo 368 Código Penal/Ley Nº 19.620, publicada el 05.08.1999, que dicta normas sobre adopción de menores, en su artículo 43 establece circunstancias que agravan sanción y que cambian la pena original/Ley $\mathrm{N}^{\circ} 19.659$, publicada el 27.12.1999, que establece sanciones a procedimientos de cobranzas ilegales, caso de modificación al $\mathrm{N}^{\circ} 3$ del artículo 296 del Código Penal, en que se tipifica la amenaza no condicional y para efectos de sanción se trata de un problema concursal normativamente regulado que ordena la sanción de una conducta a "no ser que merezca mayor pena el hecho consumado, caso en el cual se impondrá ésta"/Ley $\mathrm{N}^{\circ} 19.733$ publicada el 04.06.2001, sobre libertad de opinión e información y ejercicio del periodismo, establece agravante especial en el artículo 34 inciso segundo de esta normativa/Ley $\mathrm{N}^{\circ} 19.856$, publicada el 04.02.2003, que crea un sistema de reinserción social de los condenados sobre la base de la observación de buena conducta, en su artículo 18 define como constitutivo de agravante cometer el delito durante el tiempo correspondiente al período condonado en virtud del beneficio previsto en esta ley/Ley $\mathrm{N}^{\circ} 19.975$, publicada el 05.10.2004, normativa que modifica el Código Penal en materia de uso y porte de armas, que agrega como circunstancia agravante, el numeral 20 del artículo 12 del compendio sustantivo penal, esto es, ejecutar el delito portando armas de fuego o de aquellas referidas en el artículo 132 del cuerpo legal antes citado. Además, se incluye con un efecto de agravación en la pena a aplicar, en los delitos de robo y hurto, el inciso segundo del artículo 450 del Código Penal, que eleva la pena respectiva en un grado cuando "los culpables hagan uso de armas o sea portadores de ella"/Ley $\mathrm{N}^{\circ} 20.000$, publicada el 16.02.2005, sobre tráfico de drogas, establece un catálogo de siete circunstancias agravantes especiales con efecto en la mutación de la pena original de la ilicitud configurada/Ley $\mathrm{N}^{\circ}$ 20.064, publicada el día 29.09.2005, que aumenta las penas en los casos de delitos de maltrato de obra a carabineros, en su artículo 416 ter del Código de Justicia Militar y además, el artículo 17 ter, del Decreto Ley $\mathrm{N}^{\circ} 2.460$, de 1979, Ley Orgánica de la Policía de Investigaciones de Chile/Ley $\mathrm{N}^{\circ}$ 20.066, publicada el 07.10.2005, normativa que establece la Ley de Violencia Intrafamiliar, con la sustitución del artículo 400 del Código Penal, por el que se incluye en la preceptiva antes aludida.
\end{abstract}

\title{
Anexo $\mathbf{N}^{\circ} 20$
}

Ley $\mathrm{N}^{\circ}$ 19.366, publicada el día 30.01.1995, que sanciona el tráfico ilícito de estupefacientes y sustancias sicotrópicas, en su artículo 24, primera parte, expresa que "Los delitos de que trata esta ley se sancionarán como consumados desde que haya principio de ejecución”/Ley $\mathrm{N}^{\circ}$ 19.846, publicada el 04.01.2003, sobre calificación de la producción cinematográfica, en el inciso primero del artículo 30, sanciona con reclusión menor en su grado medio a máximo, al que participe en la producción de material pornográfico, en cualquier soporte, en cuya elaboración hayan sido utilizados menores de dieciocho años. De este modo, la ejecución delictiva del cómplice se asimila a la del autor/Ley $\mathrm{N}^{\circ}$ 19.925, publicada el 19.01.2004, sobre expendio y consumo de bebidas alcohólicas, que en el inciso tercero del artículo 42 sanciona con iguales penas a quienes indujeren ".... menores de edad al consumo de bebidas alcohólicas, sea directamente o por medio de publicidad"/Ley $\mathrm{N}^{\circ} 19.927$, publicada el 14.01.2004, en cuanto modifica el artículo 30 de la Ley $\mathrm{N}^{\circ}$ 19.846, sobre calificación de la producción cinematográfica y 
Nilo - Normativa sustantivo-penal durante los gobiernos de Aylwin, Frei y Lagos...

sanciona la participación (la cursiva es mía) en la producción de material pornográfico en cuya elaboración hayan sido utilizados menores de dieciocho años y la comercialización, importación, exportación, distribución o exhibición de ese material, según el artículo 366 quinquies, 374 bis y 374 ter del Código Penal/Ley $\mathrm{N}^{\circ}$ 20.000, publicada el 16.02.2005, que regula el tráfico de drogas, en el artículo 11 sanciona al financista, que facilita sus bienes raíces o muebles "a sabiendas" de que serán destinados a la comisión de alguno de los delitos contemplados en los artículos $1^{\circ}, 2^{\circ}, 3^{\circ}$ u $8^{\circ}$ del compendio especial de drogas, y los castiga con las mismas penas previstas para tales ilicitudes. Además, se contempla el artículo 18, que establece que los delitos de esta ley se sancionarán como consumados desde que haya principio de ejecución/Ley $\mathrm{N}^{\circ}$ 20.090, publicada el 11.01.2006, que sanciona con mayor vigor el abigeato y facilita su investigación, que en el artículo 448 ter del Código Penal, en su inciso cuarto, castiga como culpable de abigeato al que beneficie o destruya una especie para apropiarse de toda ella o alguna de sus partes, actividad más propia de quien coopera con la ejecución delictual del ejecutor principal, labor propia de los cómplices.

\section{Anexo $\mathbf{N}^{\circ} 21$}

Ley $\mathrm{N}^{\circ}$ 19.366, publicada el día 30.01.1995, sanciona el tráfico ilícito de estupefacientes y sustancias sicotrópicas, que en su artículo $1^{\circ}$, inciso tercero expresa que: "Se presumirán autores del delito sancionado en este artículo quienes tengan en su poder elementos, instrumentos, materiales o equipos comúnmente destinados a la elaboración, fabricación, preparación, transformación o extracción de las sustancias o drogas que se refieren los artículos anteriores". Más bien se trata de una presunción legal inclusa en un acto preparatorio, especialmente punido como tráfico/Ley $\mathrm{N}^{\circ} 19.733$, sobre libertad de opinión e información y ejercicio del periodismo, publicada el 04.06.2001, en su artículo 39 inciso segundo contempla una presunción legal de autoría al considerar como autor, tratándose de los medios de comunicación social, al director o a quien legalmente lo reemplace al efectuarse la publicación o difusión/ Ley $\mathrm{N}^{\circ}$ 20.090, publicada el 11.01.2006, que sanciona con mayor vigor el abigeato y facilita su investigación. Se establece en el inciso primero del artículo 448 quáter del Código Penal una presunción legal de autoría para los casos de aquellos que en su poder se encuentren animales o partes de los mismos, y que no puedan justificar su adquisición o legítima tenencia, o el caso de quien es habido en predio ajeno, arreando, transportando, manteniendo cautivas, inmovilizadas o maniatadas dichas especies animales.

\section{Anexo $\mathbf{N}^{\circ} 22$}

Ley $\mathrm{N}^{\circ}$ 19.327, publicada el 31.08.1994, que regula la comisión de delitos con ocasión de espectáculos de fútbol profesional. En su inciso segundo el artículo $6^{\circ}$ de esta ley refiere: “...con la misma pena será sancionado el que, en las circunstancias mencionadas, y sin cometer esos delitos, portare armas, elementos u objetos idóneos..."/Ley $\mathrm{N}^{\circ} 19.366$, publicada el día 30.01.1995, sanciona el tráfico ilícito de estupefacientes y sustancias sicotrópicas, en su artículo $6^{\circ}$ sanciona "la producción, fabricación, elaboración... de precursores o sustancias químicas esenciales, a sabiendas de que su finalidad es la preparación de drogas estupefacientes o sustancias psicotrópicas..."/Ley $\mathrm{N}^{\circ}$ 20.000, publicada el 16.02.2005, que regula el tráfico de drogas, en el inciso primero del artículo $2^{\circ}, 3^{\circ}, 5^{\circ}, 8^{\circ}$ y $10^{\circ}$, además del artículo 17 de esta normativa.

\section{Anexo $\mathrm{N}^{\circ} 23$}

Convenio internacional para la represión de financiación del terrorismo, publicado el 13 de septiembre de 2002. 


\begin{abstract}
Anexo $\mathbf{N}^{\circ} 24$
Convención de las Naciones Unidas contra la delincuencia organizada transnacional, publicado el 16 de febrero de 2005.
\end{abstract}

\title{
Anexo $\mathrm{N}^{\circ} 25$
}

a) Protocolo Facultativo de la Convención sobre los Derechos del Niño relativo a la Venta de Niños, la Prostitución Infantil y la utilización de los niños en la Pornografía, publicado el día 6 de septiembre de 2003; b) Protocolo para prevenir, reprimir y sancionar la trata de personas, especialmente mujeres y niños, publicado el 16 de febrero de 2005.

\section{Anexo $\mathbf{N}^{\circ} 26$}

Protocolo contra el tráfico ilícito de migrantes, por tierra, mar y aire, que complementa la convención de las Naciones Unidas contra la delincuencia organizada transnacional, publicado el 16 de febrero de 2005.

\section{Anexo No 27}

Convención Interamericana contra la fabricación y el tráfico de armas de fuego, municiones, explosivos y otros materiales relacionados, publicado el 18 de febrero de 2004.

\section{Anexo $\mathbf{N}^{\circ} 28$}

a) Convención Interamericana contra la corrupción, publicado el 02 de febrero de 1999;

b) Convención de las Naciones Unidas contra la delincuencia organizada transnacional, en cuanto penaliza la corrupción, publicado el 16 de febrero de 2005.

\section{Anexo $\mathbf{N}^{\circ} 29$}

Convención Americana sobre Derechos Humanos, denominada Pacto de San José de Costa Rica. Decreto $N^{\circ} 873$, que promulga convención, publicado en el Diario Oficial el 05 de enero de 1991.

\section{Anexo $N^{\circ} 30$}

a) Convención de las Naciones Unidas contra el Tráfico Ilícito de Estupefacientes y Sustancias Sicotrópicas, publicado el Diario Oficial el 20 de agosto de 1990; b) Acuerdo con el gobierno de los Estados Unidos Mexicanos sobre cooperación para combatir el narcotráfico y la fármaco-dependencia, publicado en el Diario Oficial el 26 de diciembre de 1991; c) Acuerdo entre los gobiernos de las Repúblicas de Chile y de El Salvador sobre prevención, control, fiscalización y represión del uso indebido y tráfico ilícito de estupefacientes y sustancias psicotrópicas y sus precursores y productos químicos específicos, publicado el 29 de diciembre de 1993; d) Acuerdo entre los gobiernos de las Repúblicas de Chile y de Venezuela sobre prevención, control, fiscalización y represión del consumo indebido y tráfico ilícito de estupefacientes y sustancias psicotrópicas, publicado el 26 de enero de 1994; e) Acuerdo con Uruguay sobre prevención, control, fiscalización y represión del consumo indebido y tráfico ilícito de estupefacientes y sustancias psicotrópicas y sus precursores y productos químicos específicos, publicada 02 de marzo de 1994; f) Acuerdo entre el gobierno de la República de Chile y el gobierno de Jamaica sobre prevención, control, fiscalización y represión del consumo indebido y tráfico ilícito de estupefacientes y sustancias psicotrópicas y sus precursores y productos químicos específicos, publicada el 25 de abril de 1994; g) Acuerdo con Costa Rica sobre prevención, control, fiscalización y represión del uso indebido y tráfico ilícito de 
Nilo - Normativa sustantivo-penal durante los gobiernos de Aylwin, Frei y Lagos...

estupefacientes y sustancias psicotrópicas y sus precursores y productos químicos específicos, publicada el 03 de enero de 1996.

\section{Anexo No 31}

a) Convención sobre los Aspectos Civiles del secuestro internacional de niños, publicada el 17 de junio de 1994; b) Protocolo Facultativo de la Convención sobre los Derechos del Niño relativo a la Venta de Niños, la Prostitución Infantil y la utilización de los niños en la Pornografía, publicado el día 6 de septiembre de 2003.

\section{Anexo $\mathbf{N}^{\circ} 32$}

Protocolo para la represión de actos ilícitos contra la seguridad de las plataformas fijas emplazadas en la plataforma continental, publicado el 06 de agosto de 1994.

\section{Anexo $\mathbf{N}^{\circ} 33$}

a) Convención marco de las Naciones Unidas, sobre el cambio climático, publicado el 13 de abril de 1995; Convenio sobre la diversidad biológica, publicado el 6 de mayo de 1995; b) Protocolo para la protección del Pacífico sudeste contra la contaminación radiactiva, publicado el 17 de agosto de 1995; c) Protocolo al Tratado Antártico sobre Protección del Medioambiente, publicado el 18 de febrero de 1998; d) Promulga el Convenio de Estocolmo sobre contaminantes orgánicos persistentes y sus anexos, publicado el 19 de mayo de 2005.

\section{Anexo No 34}

Protocolo Facultativo de la Convención sobre los Derechos del Niño relativo a la Venta de Niños, la Prostitución Infantil y la utilización de los niños en la Pornografía, publicado el día 6 de septiembre de 2003.

\section{Anexo $\mathbf{N}^{\circ} 35$}

Convención sobre los Derechos del Niño. Ministerio de Relaciones Exteriores, publicado en el Diario Oficial el 27 de septiembre de 1990.

\section{Anexo $N^{\circ} 36$}

Convención Interamericana para prevenir, sancionar y erradicar la violencia contra la mujer, publicado el 11 de noviembre de 1998. 
REJ - Revista de Estudios de la Justicia - No 13 - Año 2010

\section{BIBLIOGRAFÍA}

* Aguirre, Patricia: Ley de Violencia Intrafamiliar, Análisis Jurídico, Conosur, Santiago, 1999.

- BECK, Ulrich: La sociedad del riesgo mundial, En busca de la seguridad perdida, Trad. CARBÓ, Rosa, Paidós, Barcelona, 2008.

La sociedad del riesgo, Hacia una nueva modernidad, Trad. NAVARRO, Jorge: JIMÉNEZ, Daniel y BORRÁS, María, Paidós, Barcelona, 2006.

* BRANDARIZ, José: "Nuevos Riesgos, Nuevas Ansiedades y Expectativas Sociales en Materia de Seguridad ante el Delito", en FARALDO, Patricia (Dir.), PUENTE, Luz y SOUTO, Eva (Coords.), Derecho Penal de Excepción, Terrorismo e Inmigración, Tirant lo Blanch, Valencia, 2007.

* CEA, Sergio y MORALES, Patricio: Control de Armas, Manual de Aplicación de la Ley $N^{\circ}$ 17.798 y su Reglamento, $3^{\circ}$ edición, Legal Publishing, Santiago, 2009.

* Defensoría Penal Pública, Memoria Anual 2007.

* DÍEZ Ripollés, José: "De la sociedad del riesgo a la seguridad ciudadana: un debate desenfocado", en BACIGALUPO, Silvana y CANCIO, Manuel (Coords.): Derecho penaly politica transnacional, Atelier, Barcelona, 2005.

* LARRAURI, Elena: Criminología Crítica y Violencia de Género, Trotta, Madrid, 2007.

* MATUS, Jean Pierre et al: "Conclusiones y propuesta para un nuevo Derecho Penal Ambiental Chileno", en MATUS, Jean Pierre (Ed.): Derecho Penal del medioambiente: estudios y propuestas para un nuevo Derecho Penal ambiental chileno, Editorial Jurídica de Chile, Santiago, 2004.

* MERA, Jorge: Hurto y Robo, Editorial Conosur, Santiago, 1995.

* POlitoff, Sergio, MATUS, Jean Pierre y RAMÍREZ, María Cecilia: Lecciones de Derecho Penal Chileno: Parte Especial, Editorial Jurídica de Chile, Santiago, 2006.

* SILVA Sánchez, Jesús-María: La expansión del Derecho Penal. Aspecto de la política criminal en las sociedades postindustriales, $2^{\mathrm{a}}$ edición, Editorial Civitas, Madrid, 2001. 